د. حجازي عبد المنعم سليمان

\title{
الثلج والثلاجون
}

\section{في هصر وبلاد الشام في العصر المملوكي}

د. حجازي عبد المنعم سليمان(")

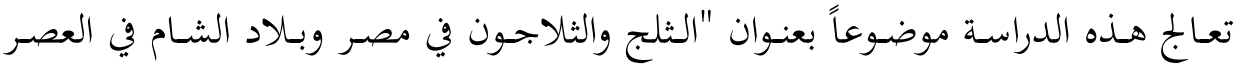

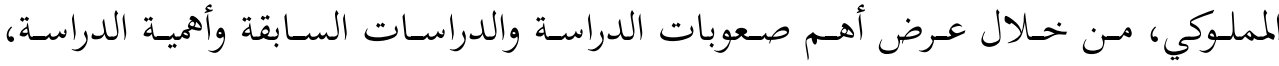
واستخدام الثلج في الفترة السـابقة على العصر المملوكي، والثلاجـون وطبيعة مهنتهم ودور

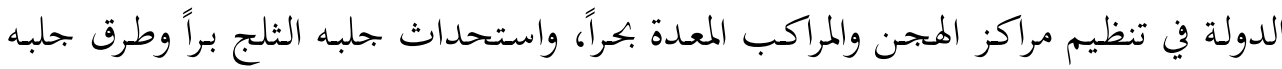
بحراً وبراً، واستخداماته في مصر وبلاد الشام، وأخيراً الثلج والعلاقات السياسية الخدات ولخارجية.

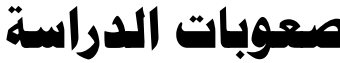

لم ير أغلب المؤرخين المعاصرين في الثلج سوى الوجه القبيح حينما يؤدي إلى الإضرار

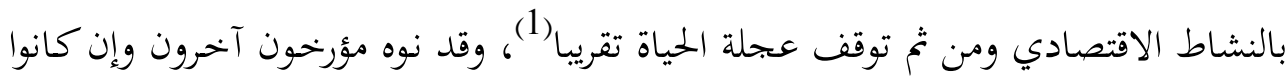

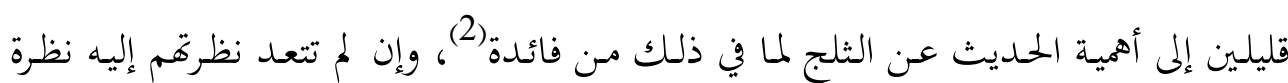

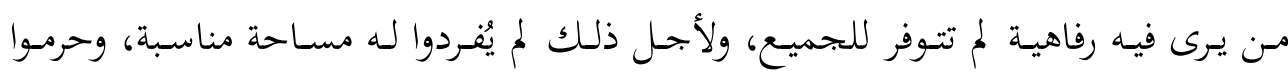
الباحثين من المادة التي تجعلهم يقيموه بشكل موضوعي.

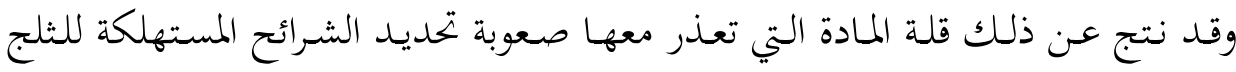

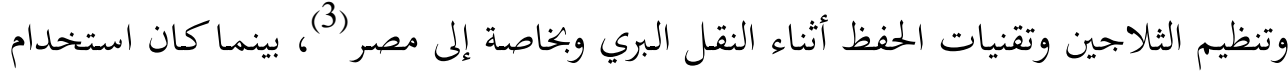

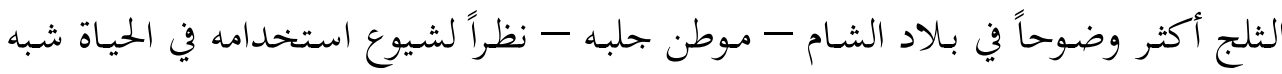

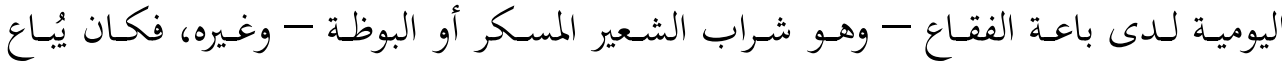

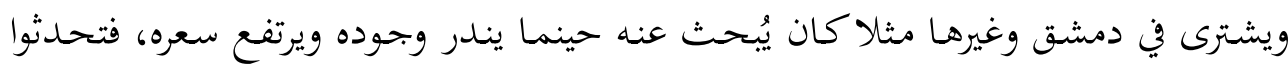

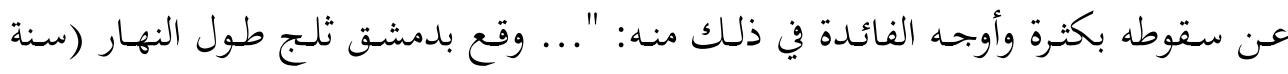

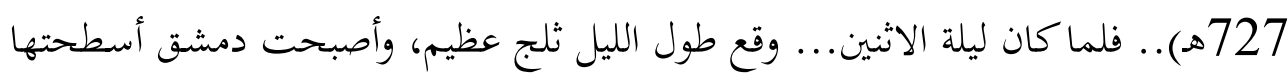

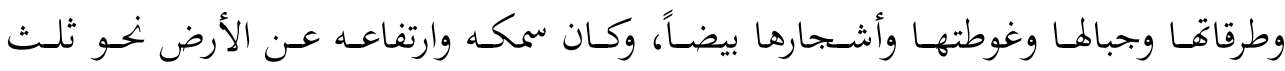




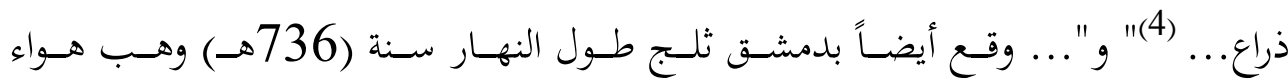

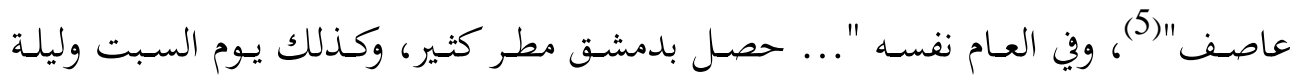
الأحد وقع ثلج كثير وبقي على الأسطحة.. وحصل به وبالمطر نفع كثير ... (6)".

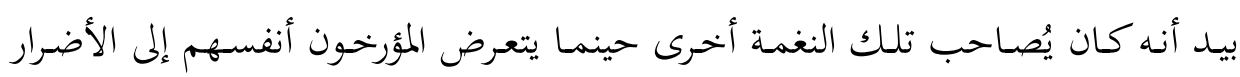

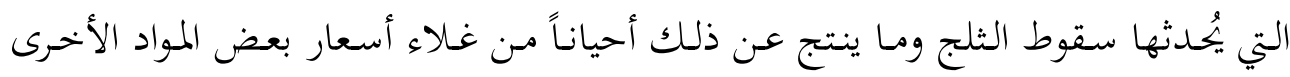

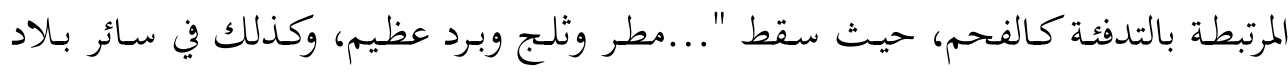

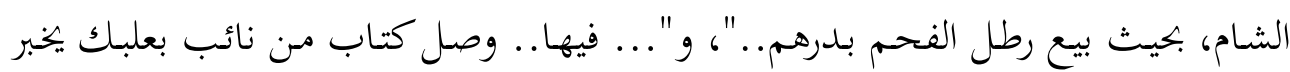

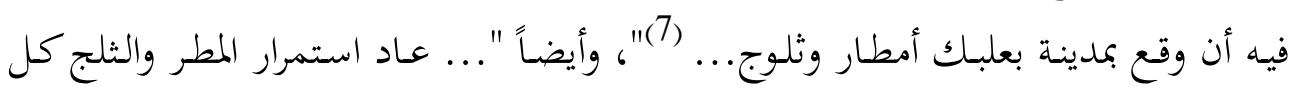

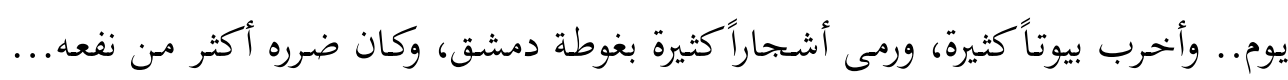

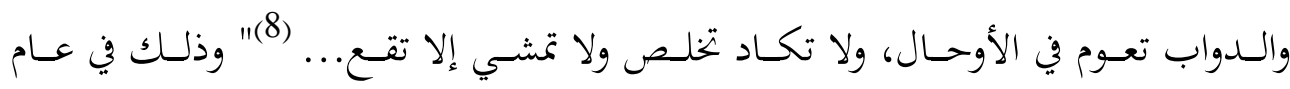

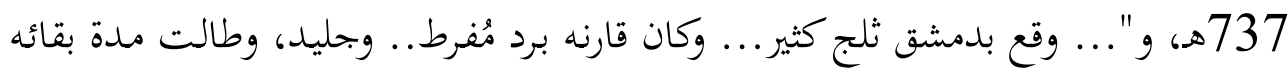

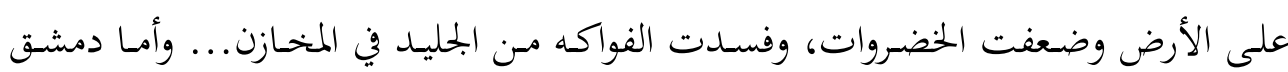
فقل أن يقع بها الثلج على هذه الصورة (9)".

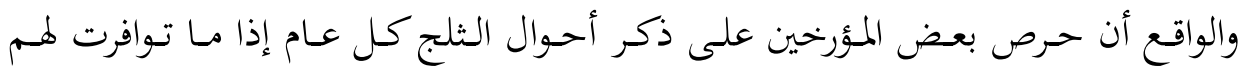

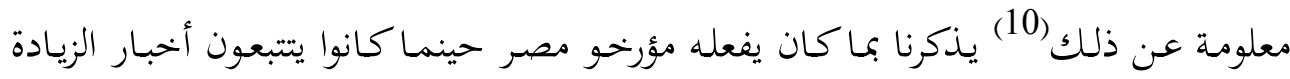

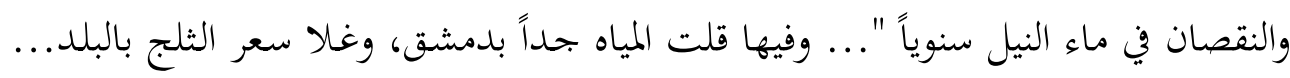

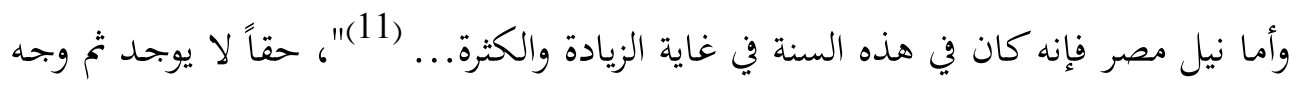

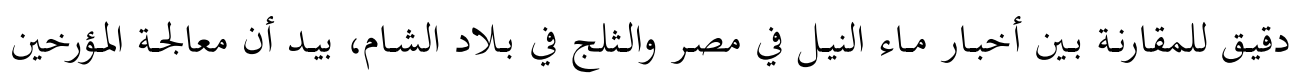

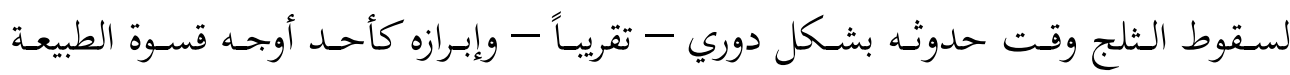

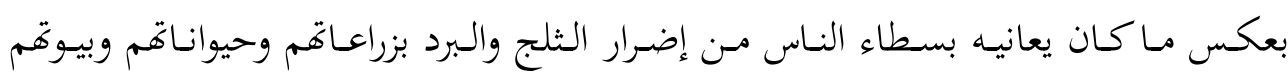

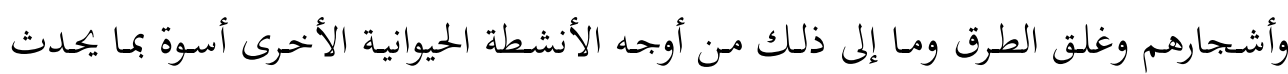
حينما ينقص ماء النيل أو يزيد (12). بينما حرص بعضهم على معالجحة الوضع الآخر والمتعلق بالجوانب الترفيهية الممثلة في

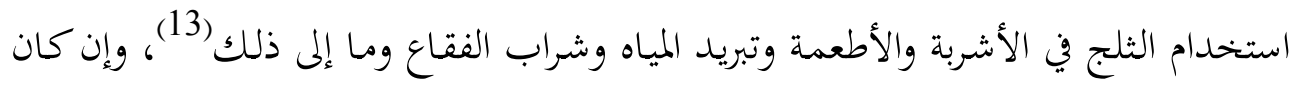

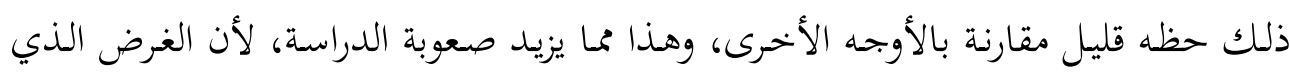




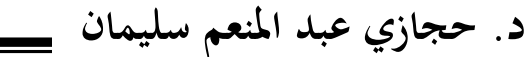

قُدمت له المادة لا يتوافق مع منهج الباحث؛ فالأول يُبرز جانباً من غضب الطبيعة وقسوقا، والآخر يهدف إلى إيضاح دور ترفيهي شكل جانباً مهماً من النشاط البشري في تلك الفترة، واللافت للنظر أن المـادة المقدمـة عـن قسـوة الطبيعـة تكـاد تفـوق بكثير المقدمـة عـن الثلج كوسيلة رفاهية، وبسبب نقص المادة العلمية فقد ظلت بعض الجوانب مغلقة أمام البحث وبخاصـة كيفيـة بيع الثلج في دمشـق ومـا إذاكـان يُبـاع في مصـر للعامـة مـن الأثريـاء أم ظل استخدامه حكراً على القصر السلطاني وبعض كبار موظفيه، وتفصيل عملية دفع الرسوم والضرائب وقيمتها وتغيرها خصوصاً في بـاد الشام، وما إذا كانت عمليات جلبه إلى مصر وريكر قد ظلت قائمة بالكثرة ذاتا حتى فهاية العصر المملوكي.

\section{أهمية الدراستة:}

ولكن ما أهمية الدراسة وجدواها وبخاصة أن المؤرخين الذين أشاروا إلى عملية تنظيم جلب الثلج قد أقروا صراحة بأنه وسيلة من وسائل الترفيه المبالغ فيه "... وكانت الملوك قد اعتادت الرفاهية مع اقتدارها على تحصيل الأشياء العزيزة و ولوعهم بجلبها من الأماكن البعيدة إكمالاً لحال الرفاهية وإظهاراً لأبهة الملك، دعاهم كمال الرفاهية والأبهة إلى جلب الثلج مـ الشام إلى مصر..."، بيد أنه إذا كان الثلج بالنسبة للسلاطين والأمراء بمثابة رفاهية وليس مقوماً من ون مقومات الحياة، ومن ثم قد يكون الموضوع قليل الأهمية بالرغم من أن الدراسات التي تُعالج موضوعات متكاملة في وسائل التسلية والترفيه قد بُذل فيها جهد طيب للوقوف على أحد أوجه الحياة في العصر المملوكي وغيره، وكذا الحسال في أهمية دراسة الثلج أنه الرغم من كونه أحد وسائل الترفيه وأنه شغل جانباً من النشاط الإنساني في حقبة تاريخية محددة بمكان وزمان فإن ثمـة جهـد كبير كان يُبـل مـن قبل الدولة التي أشرفت على الجلب والنقل والتخزين، ناهيك عن البمهود الضخم الذي بذلته طائفة كبيرة من الشاميين الذين تخصصوا في عمليات قطع الثلج ونقله وتخزينه.

ويُعـد هـا الجههد أحسد الجموانـب المهمهة التي تُقـدم دراسـة للتاريخ مـن أسفل قاع المحتمع وليس من قصوره وحكامه. أما في بلاد الشام فإنه بالرغم من أن الثلج -كما الحال في مصر وغيرهـا - لم يكـن مسن أساسـات الحيـاة ولكنـه نتيجـة لوفرته وقـرب أمـاكن سقوطه صـار يُستخدم مع الوقت لدى شريحة واسعة من العامة(14). 


\section{الدراسات السابقة}

وقد تعرض لهذا الموضوع - عرضاً - عدد من المؤرخين يتصدرهم نظير حسان سعداوي

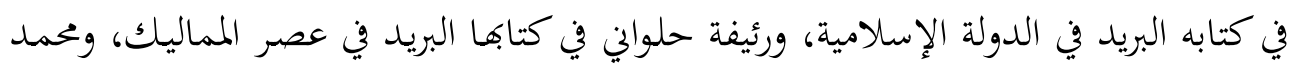

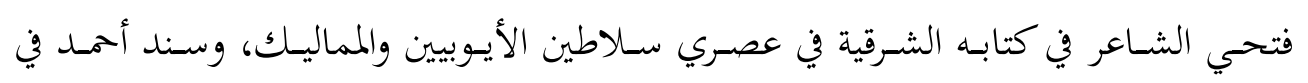

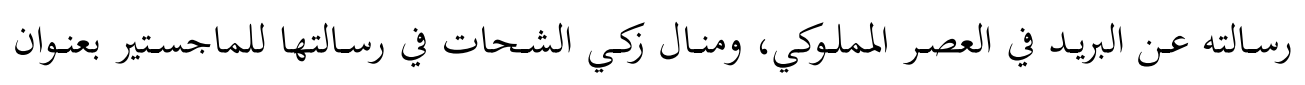

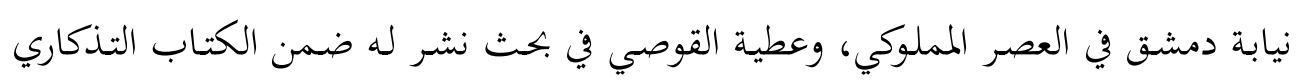

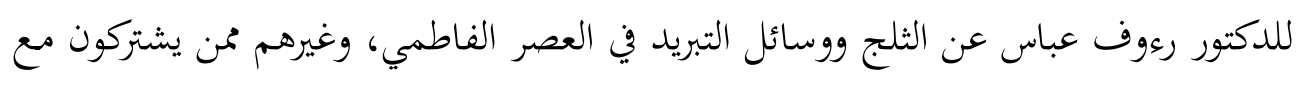

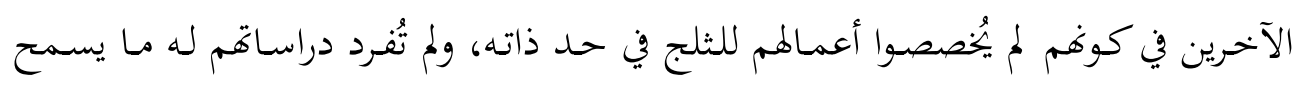

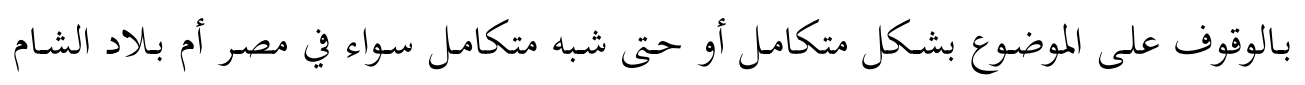
خلال العصر المملوكي.

\section{الثله قبل العصر المبهوكي}

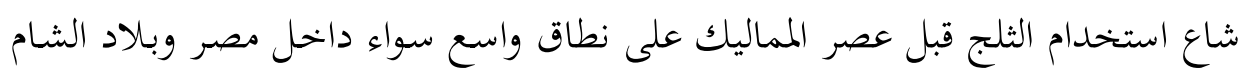

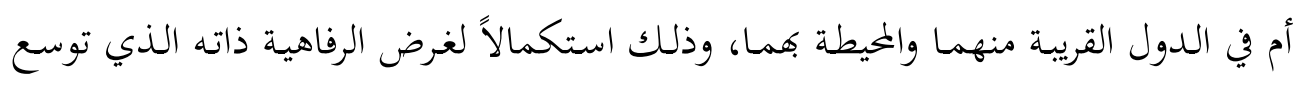

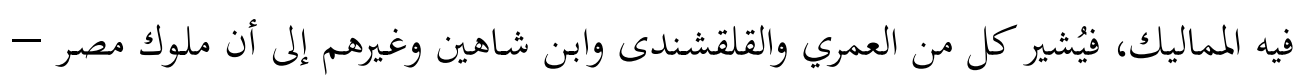

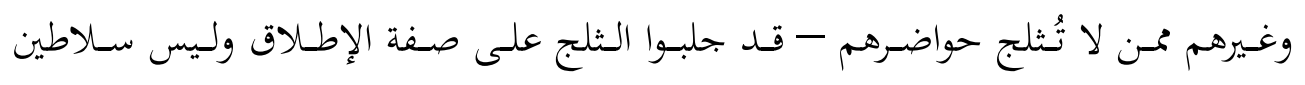

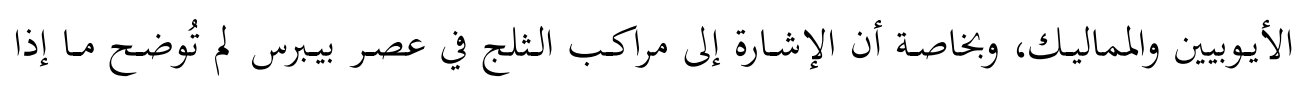

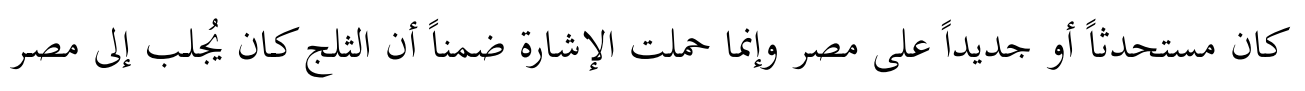

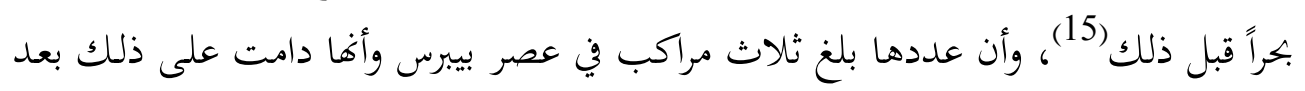

$$
\text { عصره وزادت فيما بعد. }
$$

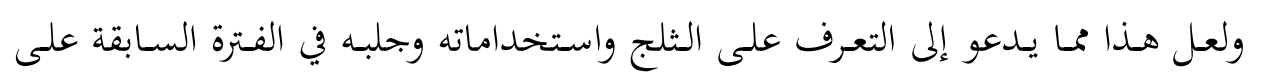

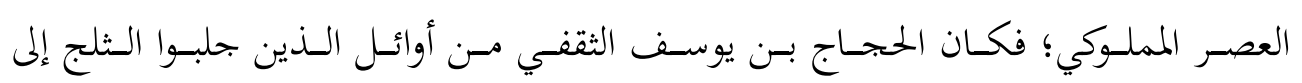

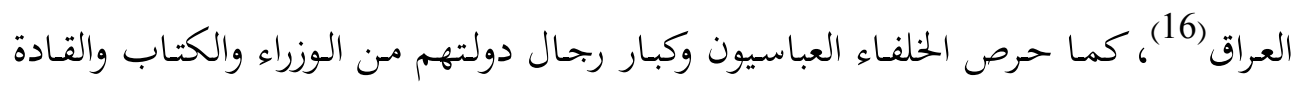

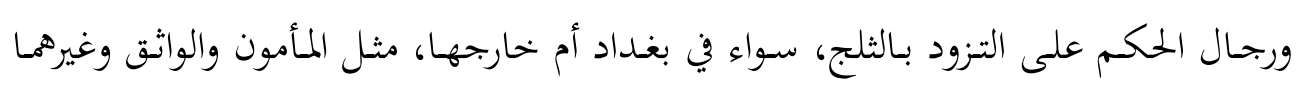

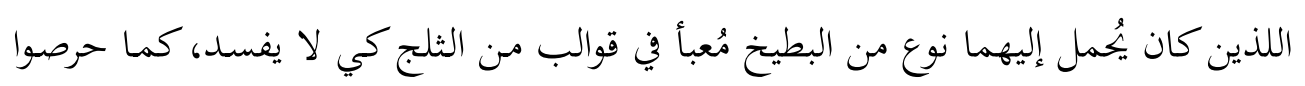

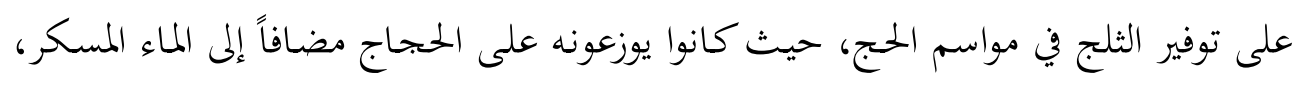


أو يُضيفونه على عصير القصب "... وفيها (أي سنة 160هـ) حج المهدي وفرق في الناس

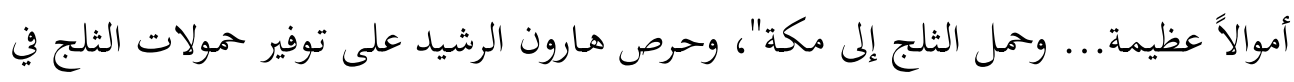

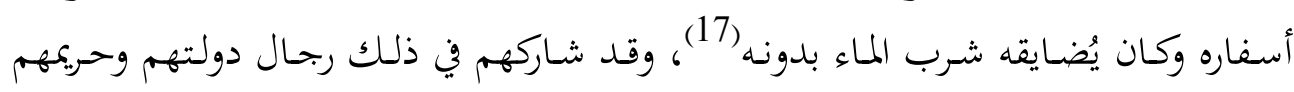

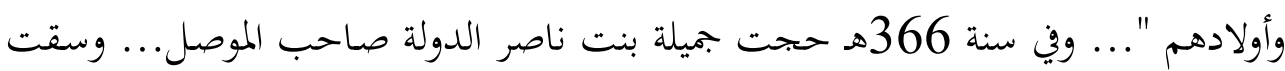
جميع الوفود سويق السكر والثلج... (18)"). ويبدو توسع بعض الخلفاء العباسيين في جلب الثلج من كثرة الإشارات التي تؤكد أهم الثم

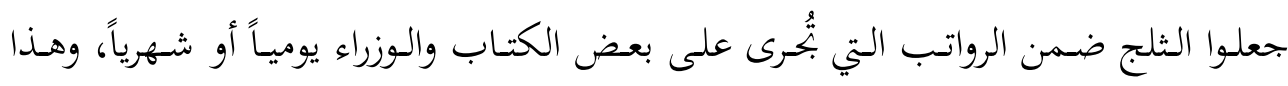

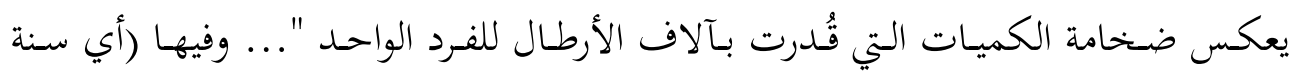

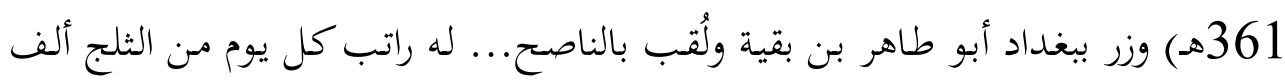

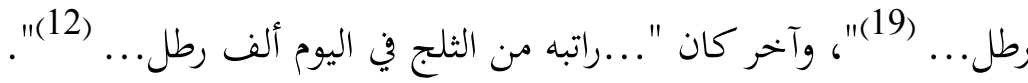

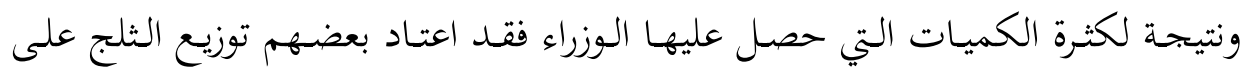

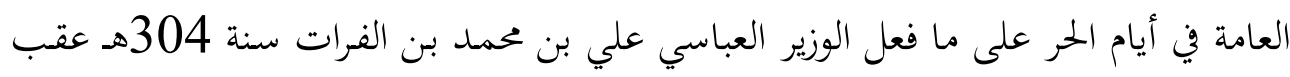

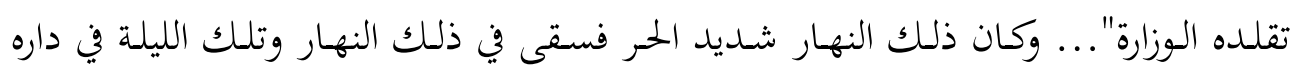

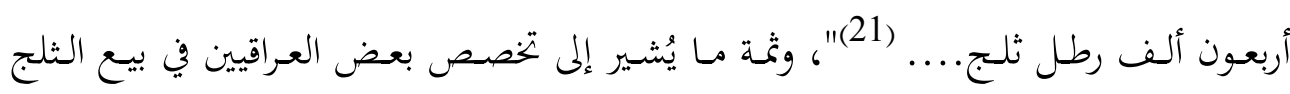

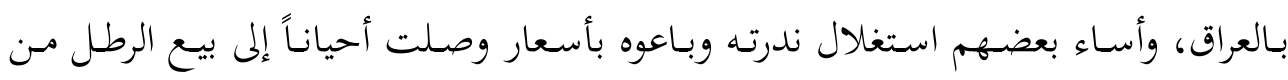

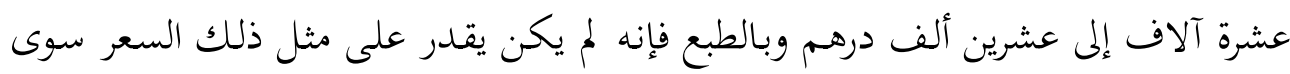

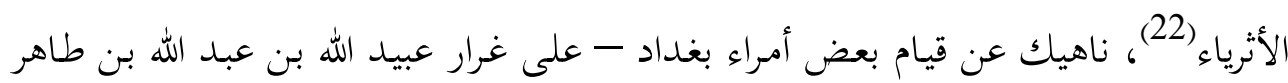

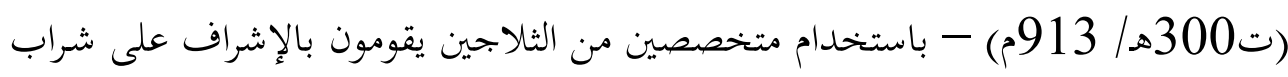

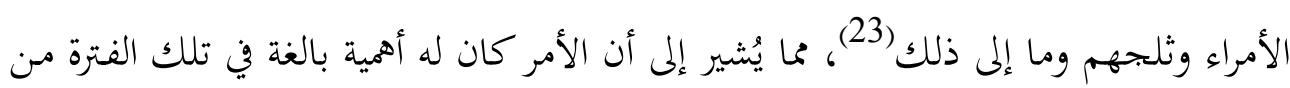
التاريخ العباسي.

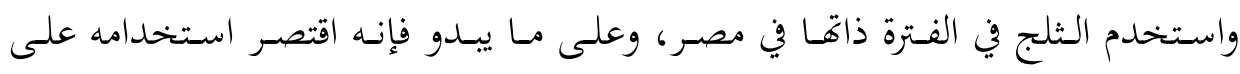

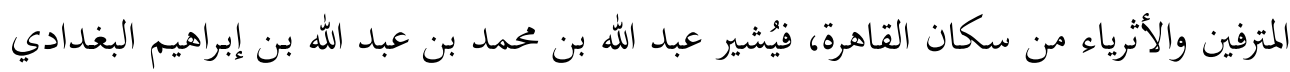

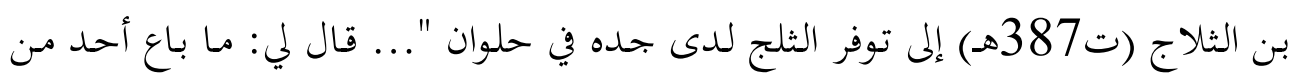

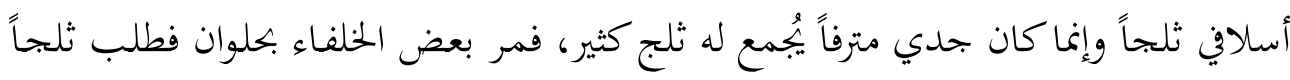

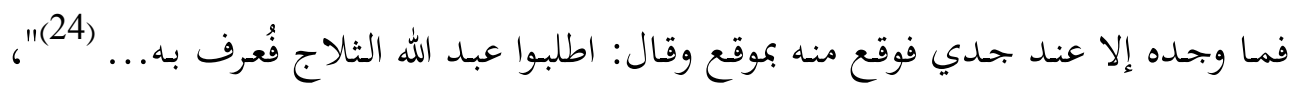




\section{الثلج والثلاجون}

ولا ريب أن دلالة طلب الثلج لأحد أهم رجال الدولة تعني معرفة رجال القصر المسبقة بتوفر الثلج في حلوان إلا ما بحث عنه أو كلف أحداً بإحضاره. والي ظل الفـاطميين في مصر كان الثلج مـن مفردات رواتب بعض كبار الأمـاء، وتعود

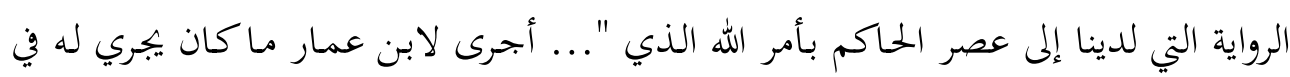
أيام العزيز ولآله وحرمه، ومبلغ ذلك... حمل ثلج عن يومين فأجرى له ذلك مدة حياته ...

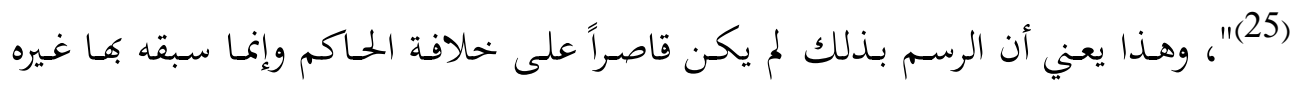
ومنهم الخليفة العزيز على ما تُشير الرواية السابقة، وحينما زار ناصر خسرو القاهرة في أواخر

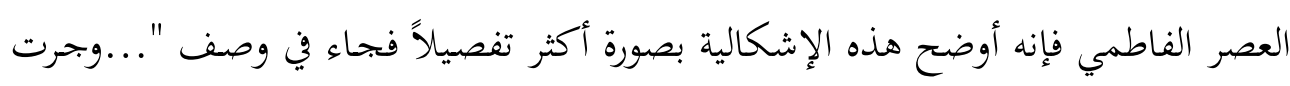

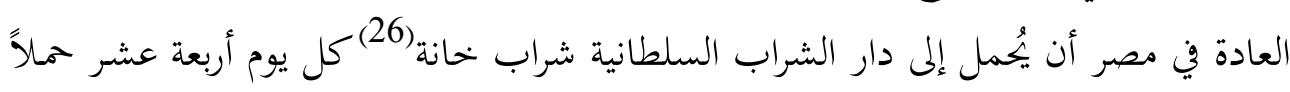

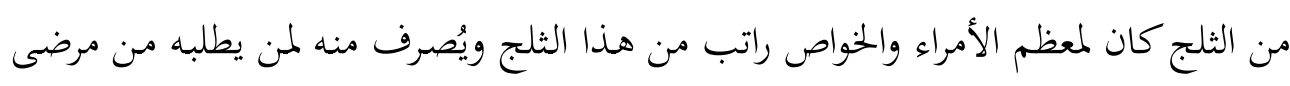

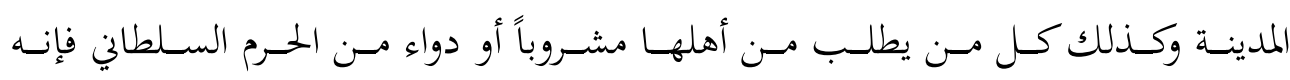
يُعطاه...(27)، والواقع أن رواية ناصر خسرو تقدم معلومة لم نقف عليها في العصر المملوكي أو غيره، وهي أنه كان للعامة أو لبعضهم نمـن لهم ظروف خحاصة نصيب في بعض كميات الثلج الواردة على القصر الخلافي.

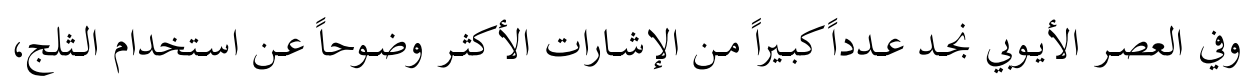
سواء في أوقات الحرب على ما نقف عليه مـن توفره في خيام سلاطين الأيوبيين في معارك

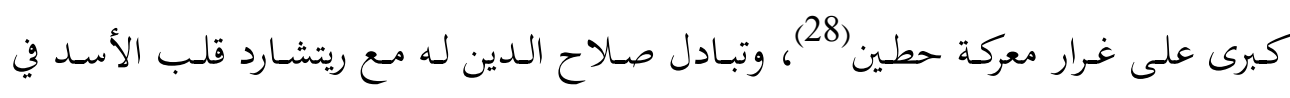
مرض الأخير "... ثم أرسل (أي ريتشارد إلى صلاح الدين) في طلب فاكهة وثلجه، فأرسل

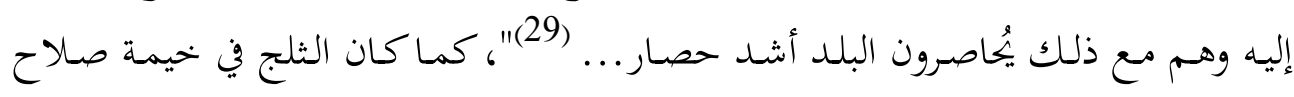
الدين في خلال مواجهاته مع ريتشارد قلب الأسد في الرملة "...فأطعمه (أي صلاح الدين والضمير عائد على أحد قادته) فاكهة قدمت من دمشق وسقاه ماءً وثلجاً.... (30)".

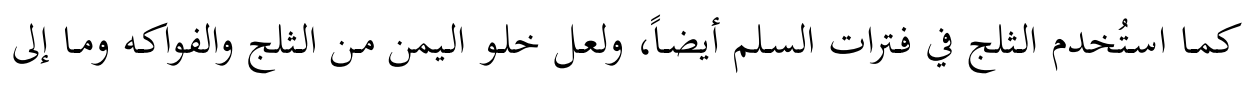
ذلك من عوامل الرفاهية كان دافعاً لطلب توران شاه شقيق صلاح الدين العود إلى بـلاد

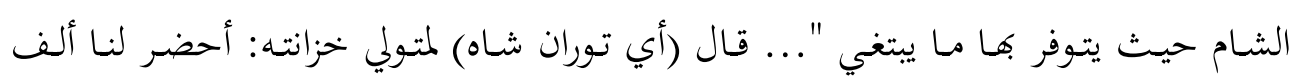

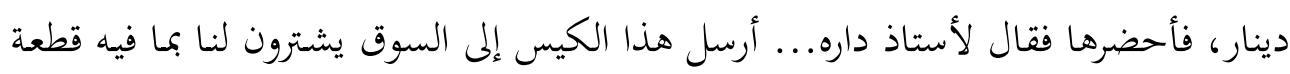


د. حجازي عبد المنعم سليمان

ثلّج، فقال أستاذ الدار: يـا مولانـا هذه بـلاد اليمن!! مـن أين يكون فيها ثلجج؟... فجعل يُعدد عليه جميع أنواع فواكه دمشق وأستاذ الدار يُظهر التعجب من كلامه... (31)". وتكفي الإشارة إلى أن الملك العادل كان شـديد الحرص على الإقامة في بـاد الشـام في فصل الصيف لأنه يتوفر فيها الفاكهة والثلج "... ولما قسم البلاد بين أولاده (الملك العادل) كان يتردد بينهم وينتقل إليهم من مملكة إلى أخرى وكان في الغالب يصيف بالشام لأجل الفواكه والثلج والميـاه البـاردة، ويشتي في الديار المصرية لاعتـدال الوقت فيها وقلة البرد....

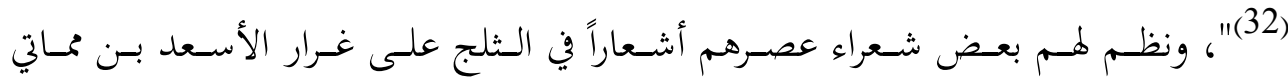
وغيره(33). ومما سبق يتضح شيوع استخدام الثلج في مصر وبلاد الشام والعراق والحجاز قبل العصر المملوكي، وأفم شاركوا غيرهم في استخدام إحدى وسائل الرفاهية.

\section{الثاج في الأدب المعاصر}

تُلحظ من خحلال الأشعار التي نظمت في الثلج بعض الدلالات التاريخية يتصدرها ربط بعض الشعراء بين توفر الثلج للملوك وبين اكتمال عظمتهم ورفاهية ملكهـم، علاوة على

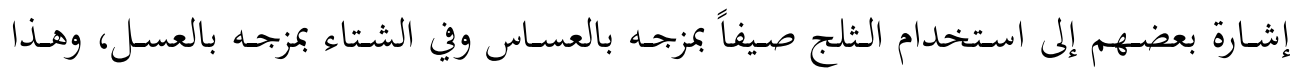
بالطبع ماكان يحدث في بالاد الشام التي يتوفر لها الثلج صيفاً وشتاءً، بينما كانت البرودة موجودة في مصر شتاءً بشكل طبيعي، إضافة إلى دلالات أخرى يُعبر أغلبها عن خلط الماء بالثلج لتبريده وهو الاستخدام الأكثر شيوعاً للثلج على مختلف العصور، كما تُلحظ إشارة بعض الشعراء إلى دلالات تاريخية مهمة للغاية؛ مثل الإشارة إلى مكان وجود الثلج في أعالي جبل الثلج أو الشيخ (34).

ولم يفت صناع الأدب النثري وبخاصة الذين عـالجوا بعض أوضاع المهمشين مثل أخبار

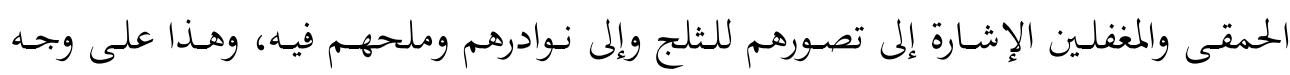

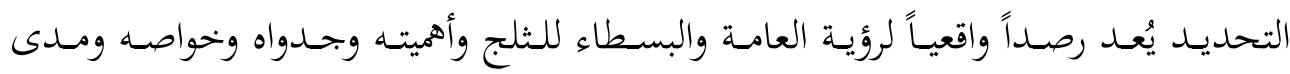

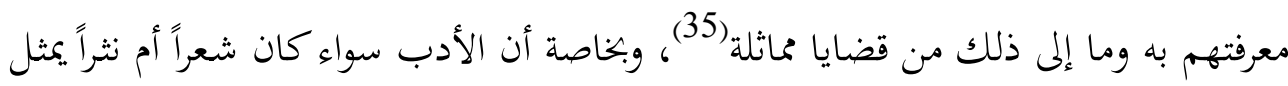

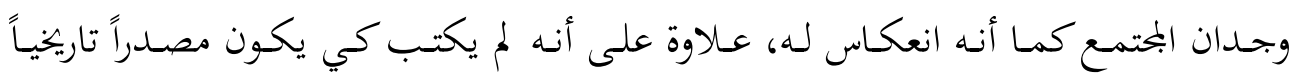
وبالتالي درجة المصداقية التي يعول عليها حينما نستقي عن الأدب مادة تخدم بعض الجوانب التاريخية التي أهملتها المصادر التاريخية أو تغاضت عنها ترفعا أو عفوياً. 


\section{الثلاجون وتقنية الحفظ ودور الدولة.}

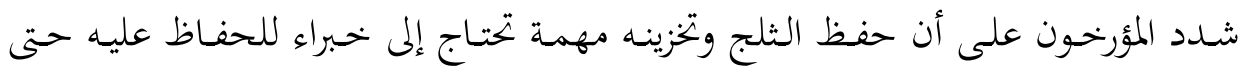

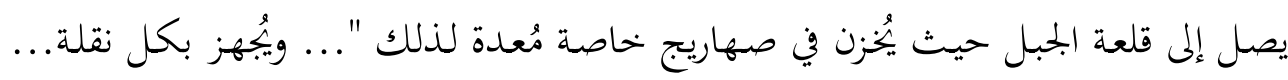

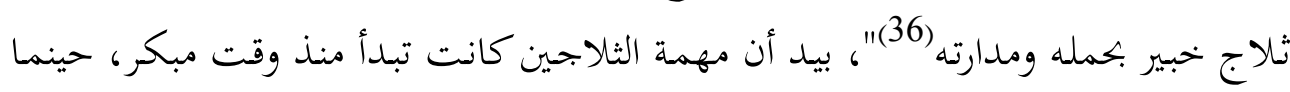

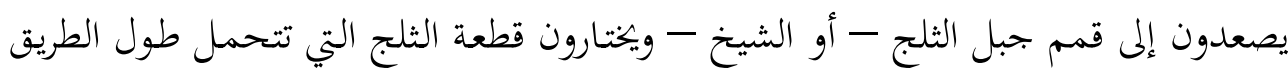

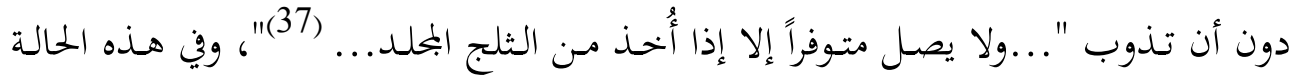

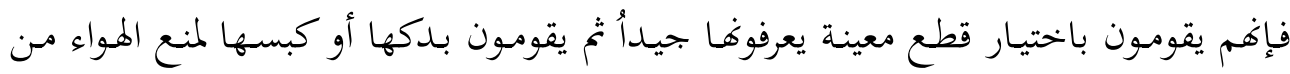
الوصول إليها "... وأُجيد كبسه واحترز عليه من المواء فإنه أسرع إذابة له من الماء... (38)".

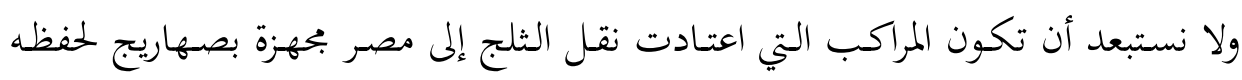

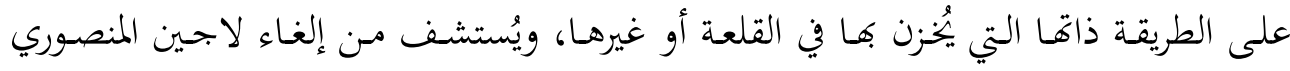

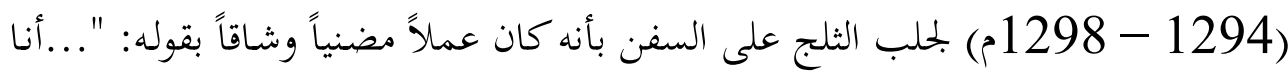

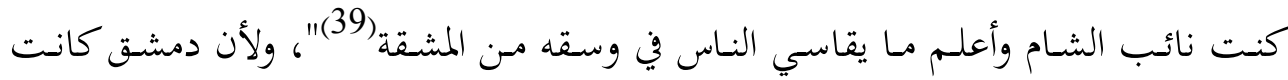

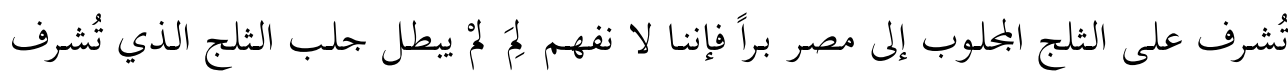

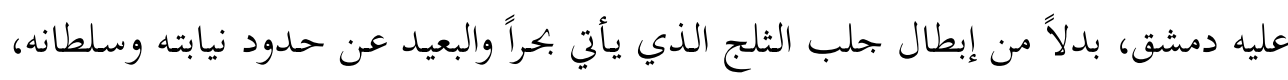

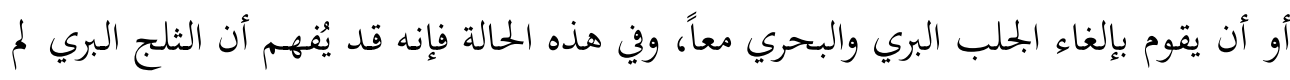

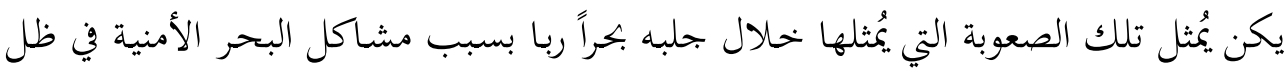

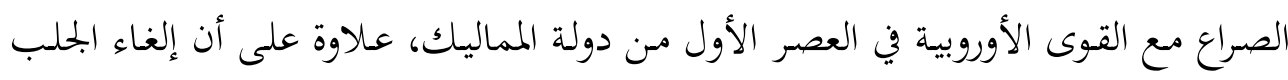

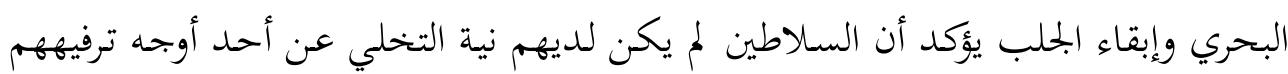
بأي صورة. بينما لم نقل على كيفية حفظه وتخزينه ريثما تصل الجمال الحاملة له إلى مصر عن طريق

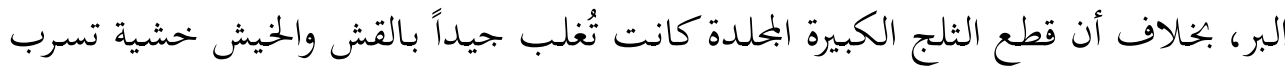

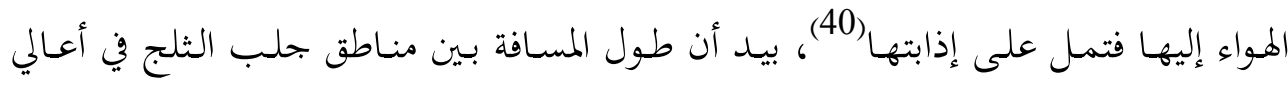

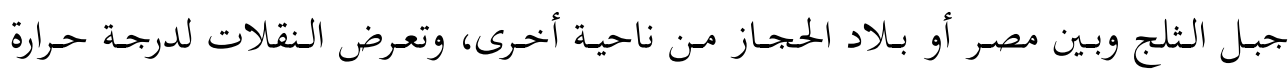

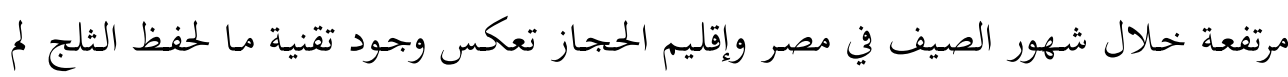
نقف عليها. 
ولكـن قــ يُفسـر الأمـر بطريقـة أخـرى مثثلـة في أن كثرة عـدد الجمــال التي حملـت الثثلج ناهيك عن السفن - وهما ينقلان كميات ضخمة على ما سنشير إليه لاحقاً - لم يكن يعني سوى أن الكمية الكبيرة التي كانت تخرج بها تلك الجمال لم يكن يصل منها إلى مصر سوى كمية قليلة، ولأجل ذلك عُولجت المشكلة بالإكثار من الحمولات في وقت متقارب لتعويض الكميات التي تذوب بفعل الحرارة، وقد أشار بعض المؤرخين إلى وجود تقنية أخرى بيد أفهم

$$
\text { لم يُسهبوا في شرح تفاصيلها. }
$$

ولكن يمكن تقديم تصور لها في ضوء إشارات من مصادر أخرى؛ فقد أشار الجزري إلى وجود خزانات للثلج في بلدة قارا(41) الواقعة شمال إقليم الحجاز كانت تمد السلاطين بالثلوج التي يستهلكوها خلال مواسم الحج (42)، ولاشك في أن هجن الثلج القادمة من دمشق هي التي كانت تمد خزانات قارا بالثلج قبيل ذلك، كما يُفهم من إشارة غامضة عثور المماليك البحرية - الذين فروا مـن وجهه عز الدين أيبك عقب مقتل أقطاي - على مدينة غامضة أطلقوا عليها المدينة الخضراء وحسدووا موقعها بأهـا تقع في تيه بني إسرائيل، أي في المنطقة

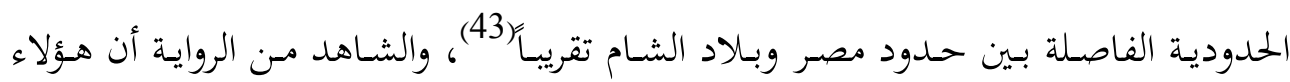
المماليك عثروا مصادفة على خزان للمياه بتلك المدينة شديدة الحرارة وقد وصفوه بأنه أبرد من الثلج (44)، وفي ضوء هذه الإشـارات مع توقع وجود تقنية معينة حفظت كميات الثلج المنقولـة طـوال ذلـك الطريـق الطويـل شــيد الحـــارة أن تكـون تلـك التقنيـة مثثلـة في تـوفير السلاطين خزانات لحفظ الثلج في محطات معينة على طول الطريق، والمعروف أيضاً أن الملح كان يُستخدم في حفظ المواد الغذائية وبخاصة السمك المملح (1) ولا نستبعد أن يكون قد تح استخدامه في حفظ الثلج للوصول به في كميات مناسبة إلى مصر وغيرها.

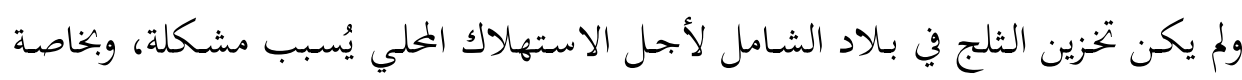
أها بلاد الثلج ولا تحتاج إلى نقله لمسافات بعيدة، وبالرغم مـ ذلك فقد خُزن الثلج في بلاد الشام ولكن لاستخدامه في فصل الصيف، حيث تخصص خبراء من الثلاجين ممن ينتمون إلى قرية حلبون(46) التابعة لدمشق في دك الثلج في مغارات طبيعية ولا يبدأ بيعه إلا في شهر أيار/ مايو (47)

أمـا في لبنـان فقد وُجـدت لهذه الغاية مباني متينة مقببـة ومطمورة جزئياتً في منحدرات 


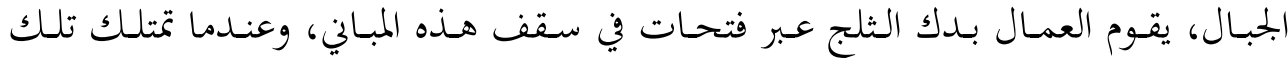

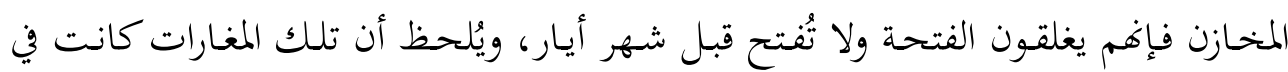

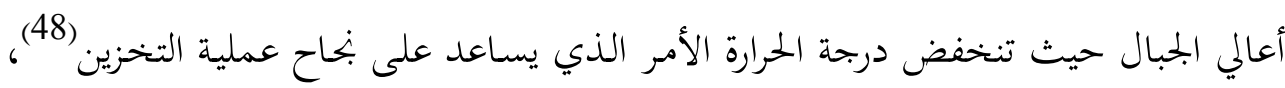

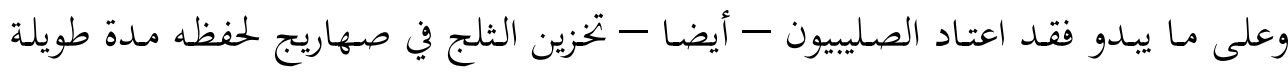

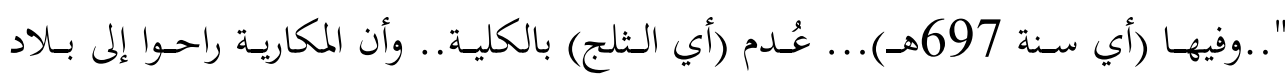

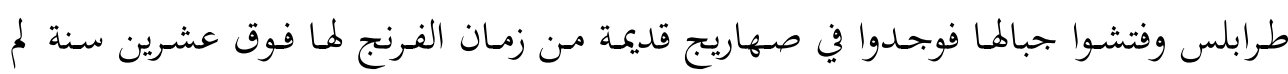
تُفتح، ووجدوا فيها قطع جليد... (49)".

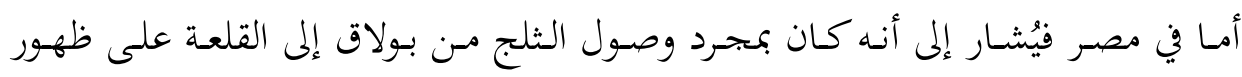

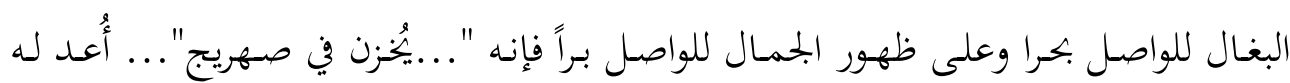

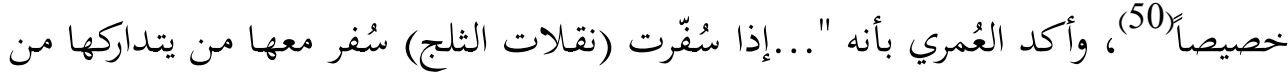

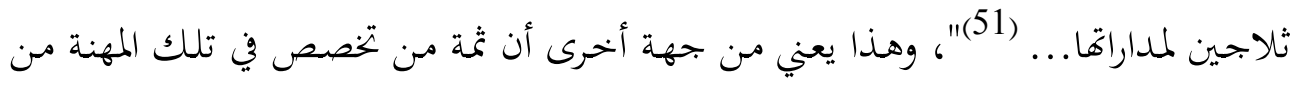

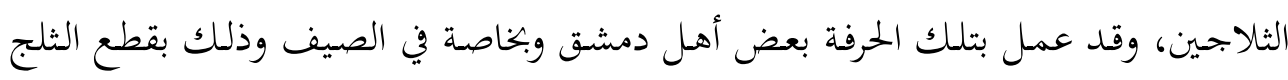

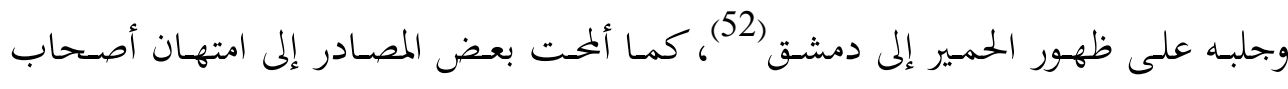

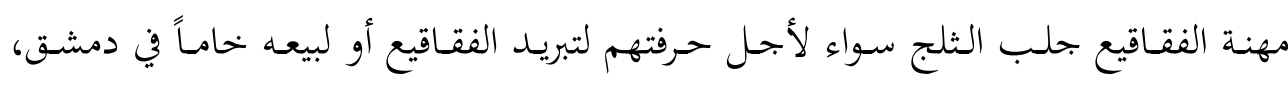

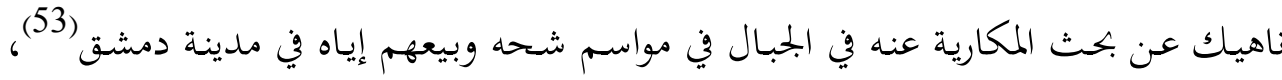

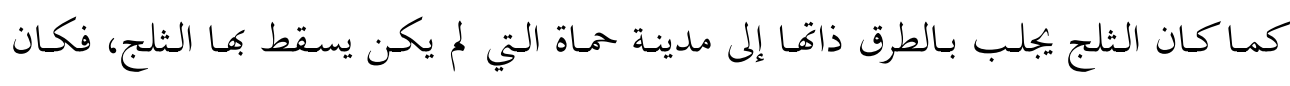

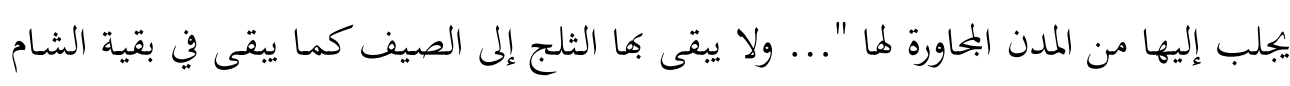
وإنما يُجلب إليها مما يجاورها وحوها.... (54)".

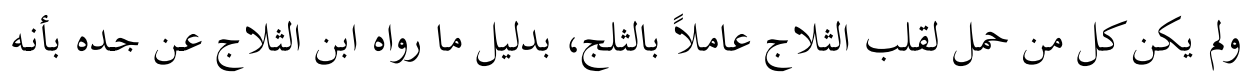

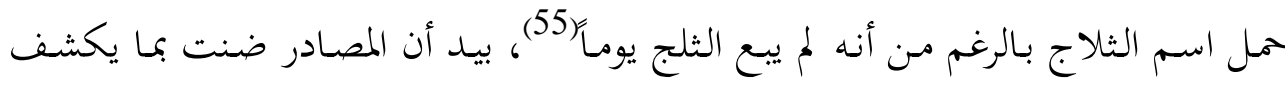

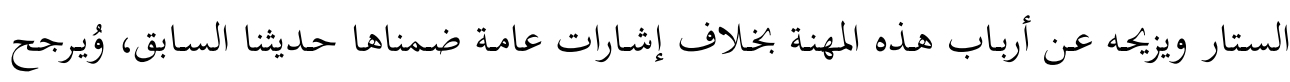

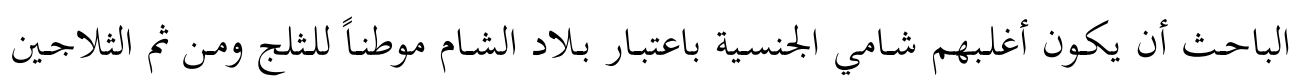
بعكس مصر، ويؤيد ذلك عودة من أشرف على نقل الثلج إلى مصر - سواء بحراً أم براً فور انتهاء مهمتهم إلى الشام (56). ولكن لم نقف لهم على تنظيم ما، وما إذا كان لهم رئيس أو شيخ، بخلاف أفهم ارتبطوا 
د. حجازي عبد المنعم سليمان

بديوان الإنشـاء على اعتبار صدور المراسيم التي حـددت أوقات عملهمم عنه، وقد نظمـت تلك المراسيم كيفية جلب الثلج إلى مصر في موعده، وفرضت لهم الدولة مكافأة لقاء جلب

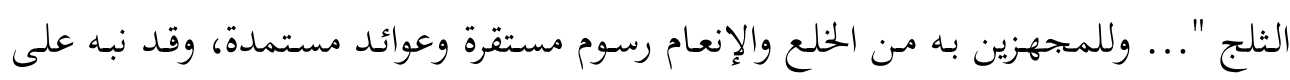

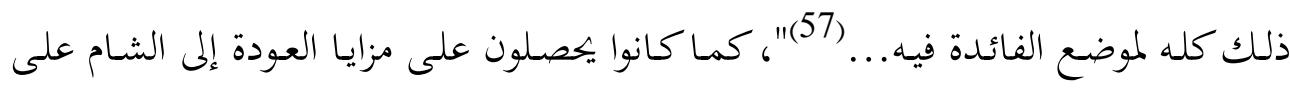

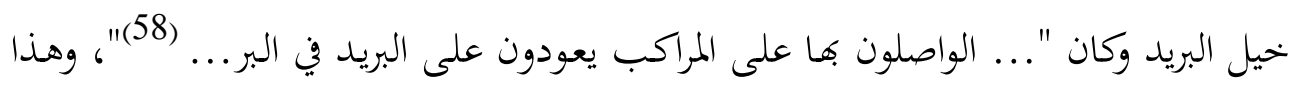
يُعد امتيازاً خاصاً لهم بالعودة إلى مواطنهم على خيول البريد.

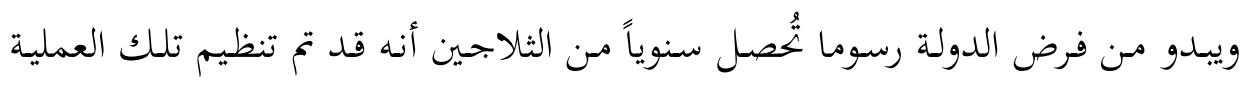
وبخاصة في دمشق، وقد ارتبطت ضريبة الثلج بنوع معين من الفاكهة وهو العنب"... "قلت:

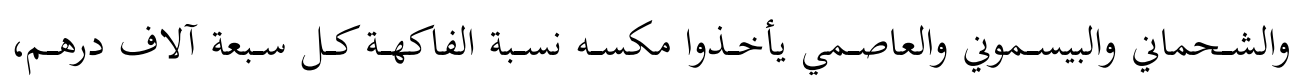
ويُباع العنب مدة ست شهور، منها أربع شهور، كل يوم من ثلاث مائة حمل إلى أربعمائة

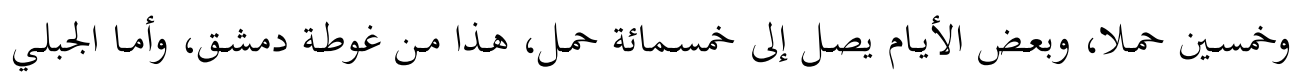

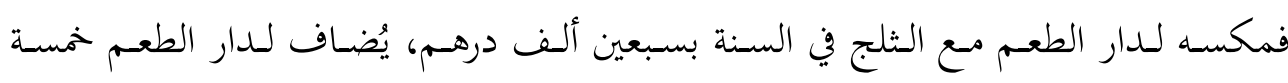
وثلاثين ألف درهم (العنب) والثلج بخمسة وثلاثين ألف درهم (59)". وأضـاف الجمزري موضحاً قيمة المكس المفـروض على الثلج مرة أخـرى بقوله "... الثلج

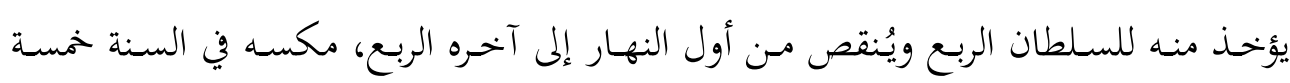

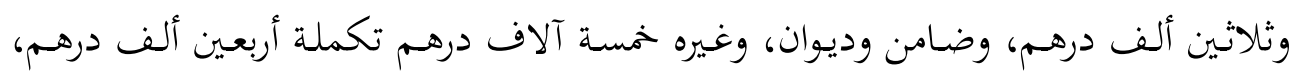
يُباع في السنة ما يُوضع على الفقاع وما يُشرب بالماء في الصيف بمائة ألف درهم وستين ألف وديرة وائ درهم (60)" وذلك في حدود عام 736هـ، كما قُدرت الضرائب المفروضة على الثلج في الرها

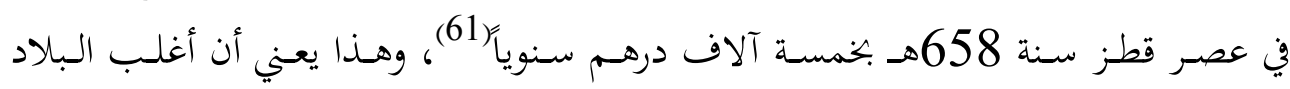

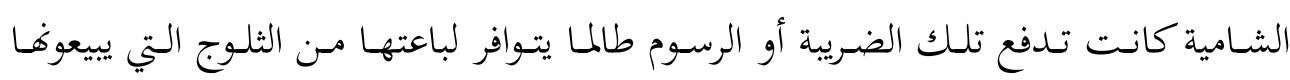
لسكان مدفهم. ولا ريب في أن تلك الرسوم كانت تُفرض إما على باعة الثلج وإما على من يستخدمون الثلج من باعة الفقاع، وقد تفاوتت أسعار الثلج في بلاد الشام بحسب توفره أو شحه، فكان

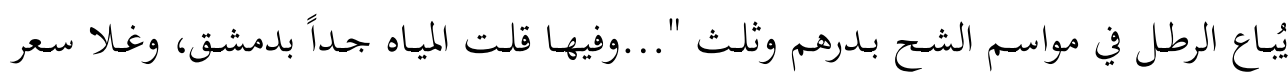

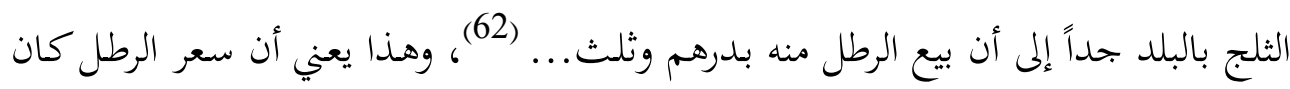


أرخص مسن ذلك في موسم توافره سواء بدرهم أول أقل، وكان العامة يقبلون على شرائه،

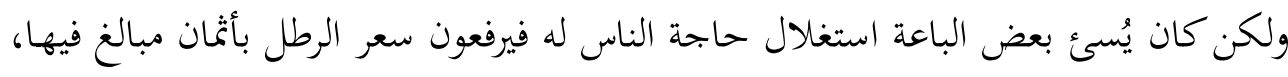

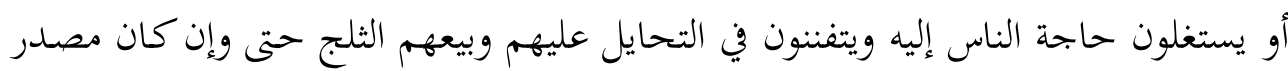

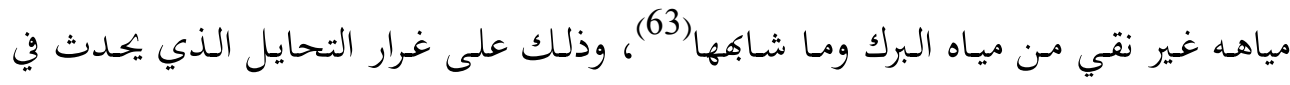
أصناف أخرى من السلع.

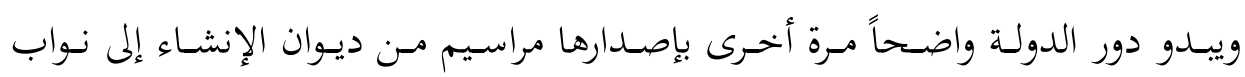

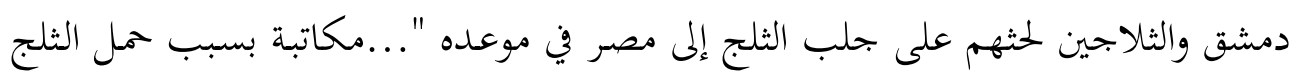

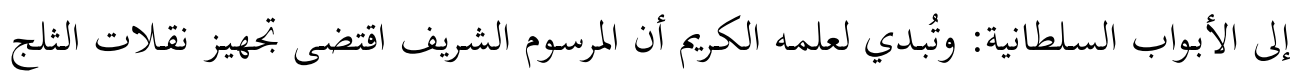

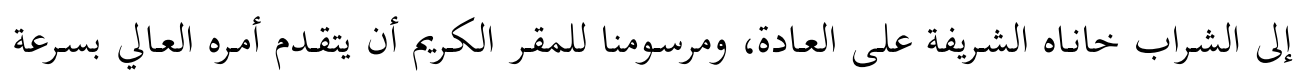

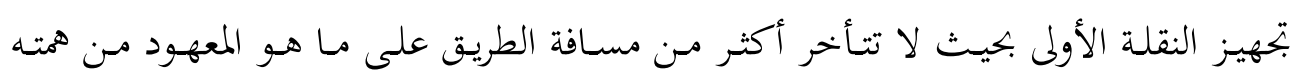

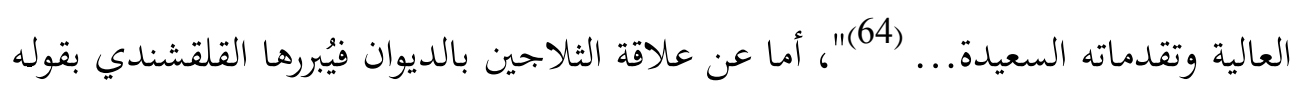

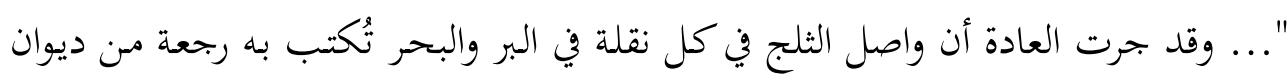

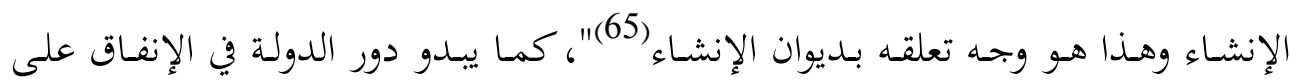

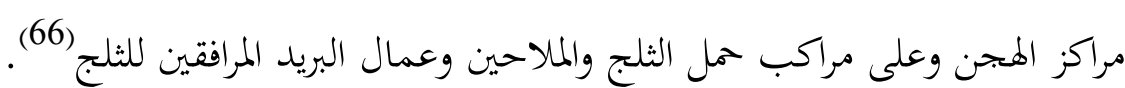

\section{نقل الثلج إلى هصر: أولا: النقل البحري}

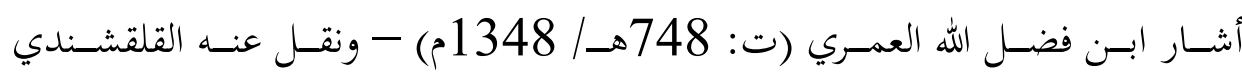

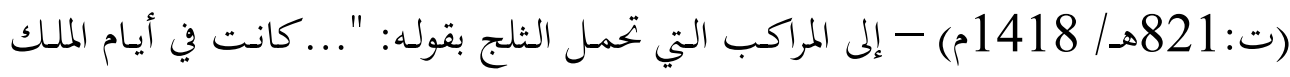

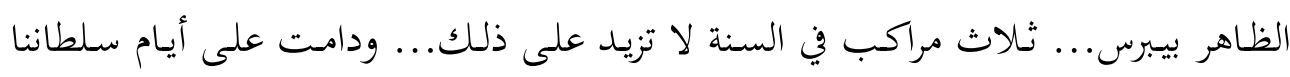

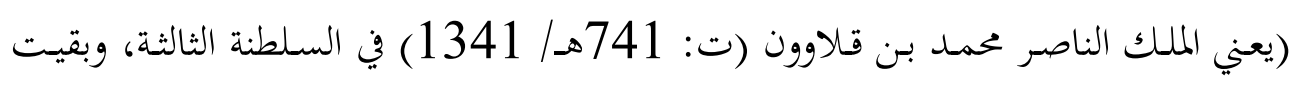

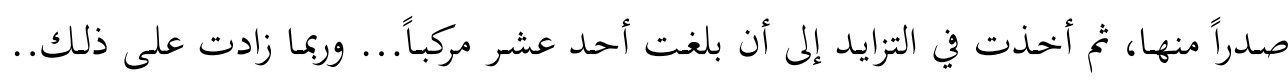

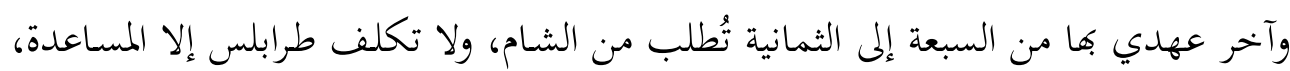
وكل ذلك بحسب اختلاف الأوقات ودواعي الضرورات... (67)". ويقدم النص بعض الترجيحات والتلميحات، منها:

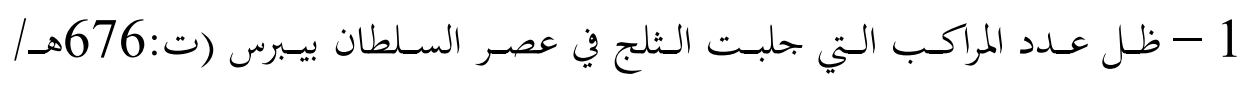


د. حجازي عبد المنعم سليمان

1277م) محـددة بـثلاث لم تـزد على ذلك حستى انتهـاء عصـر الناصـر محمـد (693 . 1293 / 1241

2 - ارتبطـت الزيـادة مـن 3 مراكـب في عهـد الظـاهر بيـبرس إلى 11 مركبـاً بإشـراف طرابلس على شحن الثلج، وهذا يُرجح أن بقـاء طرابلس في أيدي الصليبيين حتى استرداد قلاوون لما عام 688هـ/ 1289م قد أعاق الإكثار من جلب الثلج بحراً. 3 - يُلحظ ارتباط زيادة الطلب على الثلج بعصر المماليك الجراكسة، وبالرغم من قوة العصر الأول واستقراره داخلياً فإنه لم يكن كذلك على المستوى الخارجي بحيث كُثفت كافة جهود الدولة لأجل محاربة الصليبيين والمغول، الأمر الذي لم يُعط الفرصة للسـلاطين للبقاء طويلاً في مصر حتى هاية عصر الناصر محمد، بعكس الحال مع العصر الثاني الذي واكبه هدوء الجبهة الخارجية حتى ظهور الخطر البرتغالي ثم العثماني في هاية الجراكسة، بينما كثرت المشـاكل الداخلية وتراجع الاقتصاد، وبـالرغم مـن ذلك فتـد ازداد جلب الثلج طوال ذلك العصر وبكميات كثيرة، مما ينم عن بعض طرائق الحياة التي عاشها السلاطين في ظل تضخم المشاكل الداخلية والخارجية. لم يُشر القلقشندي (ت 821هـ/ 1418م) إلى كميات الثلج المحلوبة في عصره، واقتصر هو وابن شاهين الظاهري على نقل مادة العُمري عن الثلج دون تحديثها بمعلومات عصرهما، وقد امتد عصر المماليك بعد القلقشندي ما يقرب من قرن من الزمان وبعد وفاة ابن شاهين

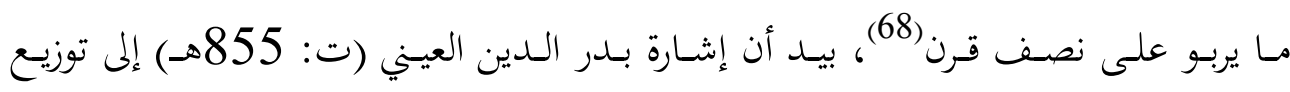
السلطان المؤيد شيخ الممودي (ت: 824هـ/ 1421م) لملاء السكر المكرر الممزوج بالثلج في بحالس العلم يُشير ضمناً إلى استمرار جلب الثلج إلى مصر حتى الربع الأول مـن القرن التاسع الهجري، ولكن دون الوقوف على الكميات المحلوبة وطرق جلبها وكيفيته (69). 4 - ظل جلب الثلج قاصراً على المراكب حتى عصر السلطان الناصر محمد بن قلاوون

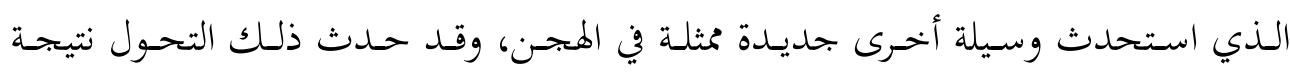
لتفضيل السلاطين استخدام الكميات المنقولة براً على المنقولة بحراً، واقتصر استخدام المنقول بحراً على توزيعه على أرباب المناصب والعمائم في الدولة "... لأنه يصلُ أنظف وآمن عاقبة على أن المسافرين يأخذذون الجاشني منه بحضور أمير بحلس وشاد الشراب خحاناه السلطانية 


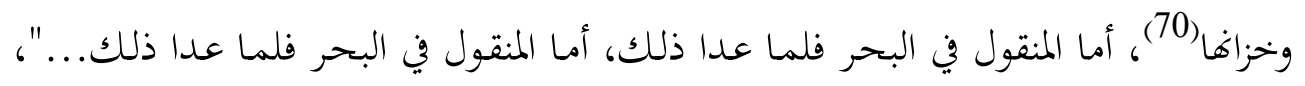

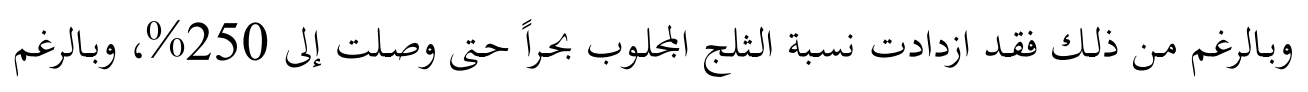

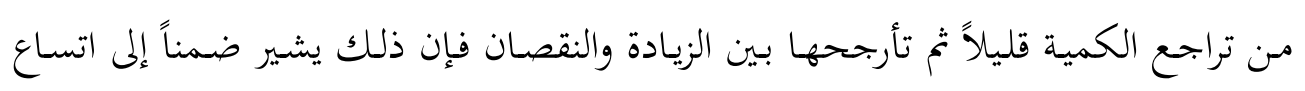

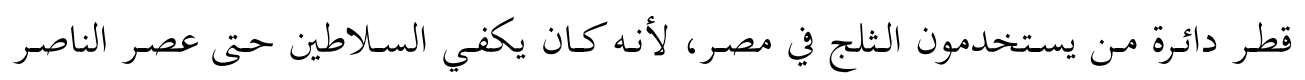

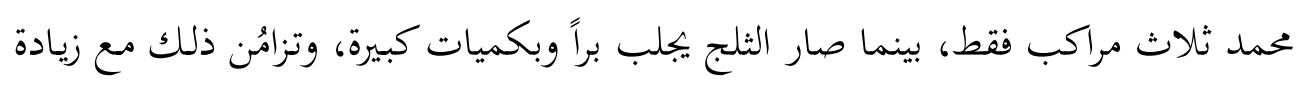
هائلة في الكميات البحلوبة بحراً.

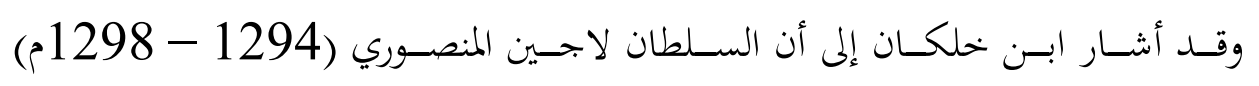

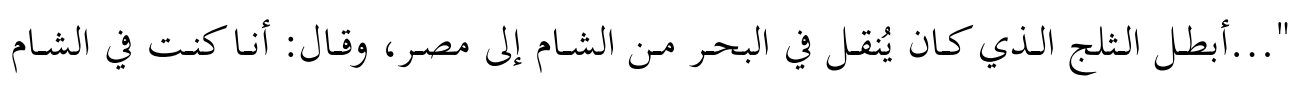

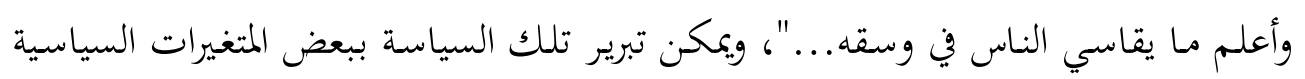

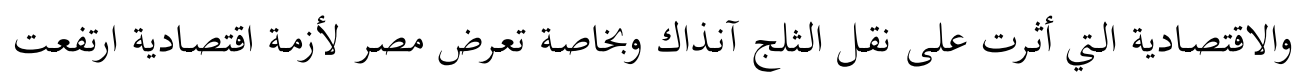

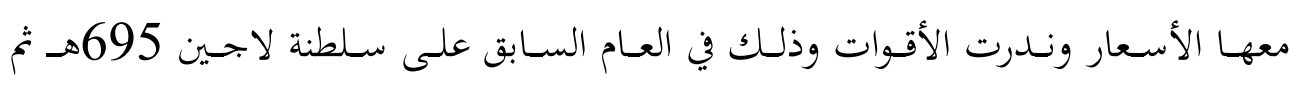

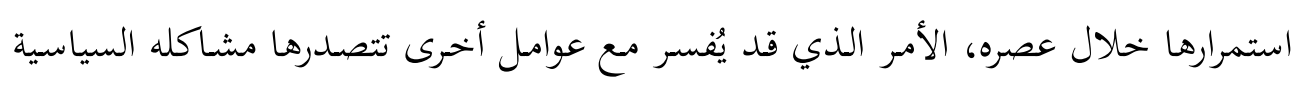

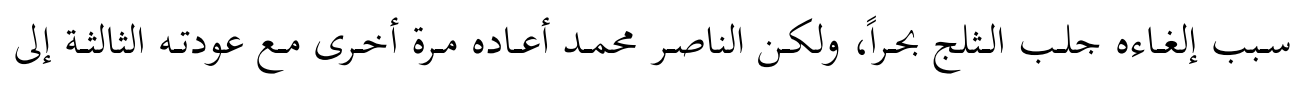
عرشه (1309 - 1341م).

\section{طريق اسفن الثلج حتى وصولها إلى الشراب خاناه في القاهرة}

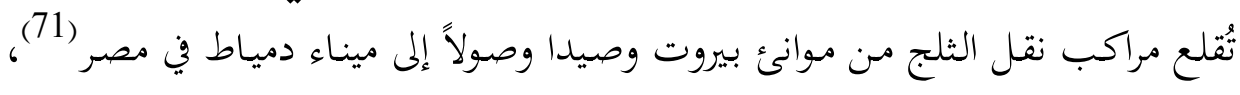

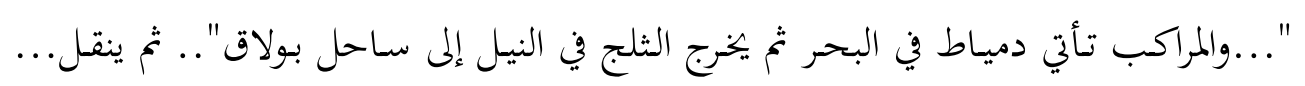

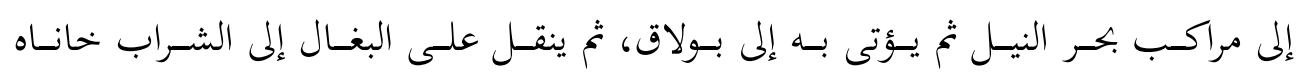

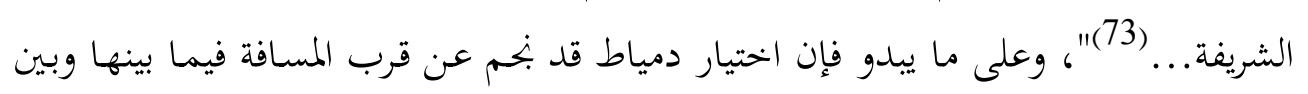

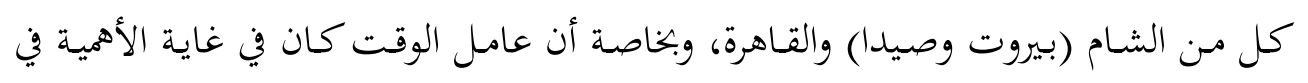

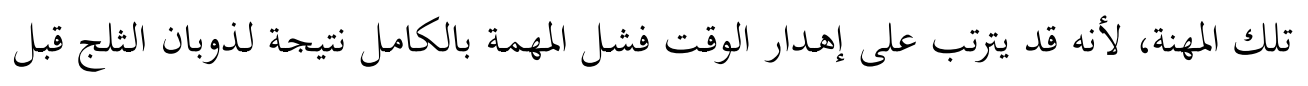
وصوله إلى الشراب خاناه وبالتالي عدم الإفادة منه.

\section{ثانيا: النقل البري \\ استمداث جلب الثلج براً}

كانت محطات هجن الثلج تتخذ من بعض مراكز البريد بين مصر وبلاد الشام محطات 
لها خلال موسم نقل الثلج، وفي ذلك يشير ابن فضل الله العمري إلى أن مراكز هجن الثلج

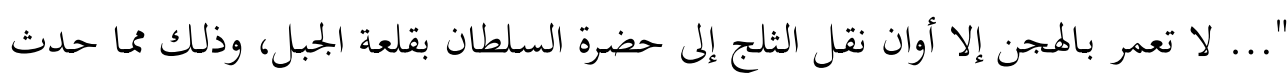

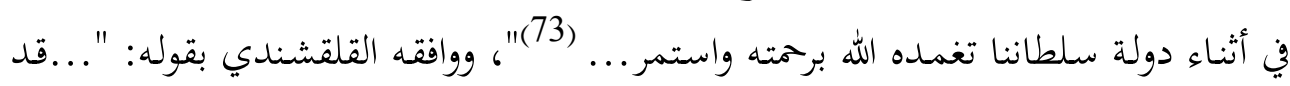
ذكر في "التعريف" أنه مما حدث في الدولة الناصرية (أي عصر الناصر محمد).... واستمر،

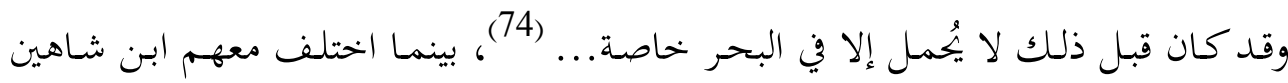

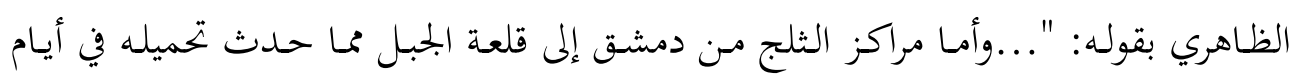

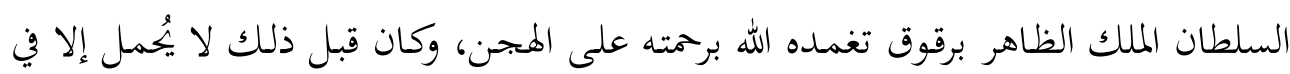
البحر خاصة من الثغور الشامية وهي بيروت وصيدا إلى ثغر دمياط المحروس... (75)".

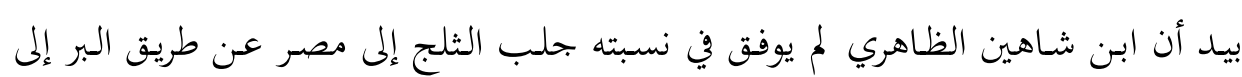

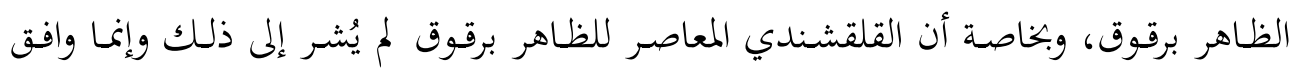

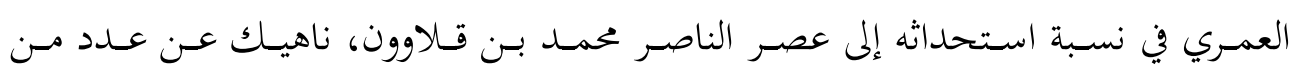

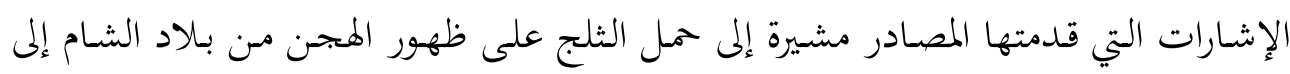

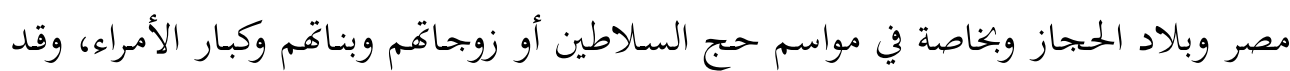

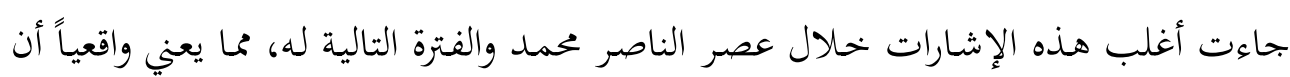

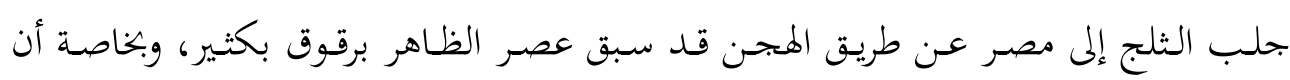

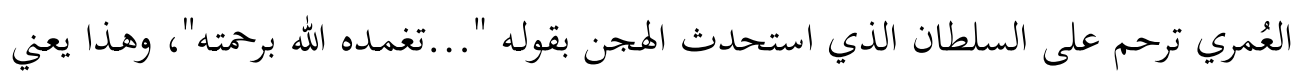

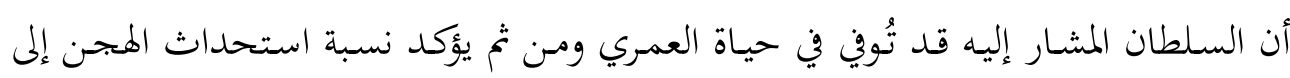
الناصر محمد وليس الظاهر برقوق.

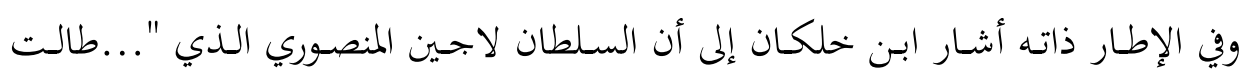

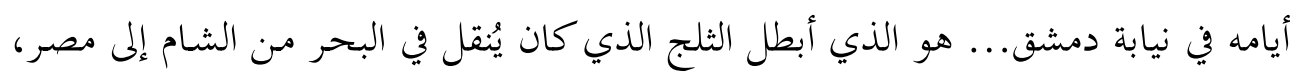

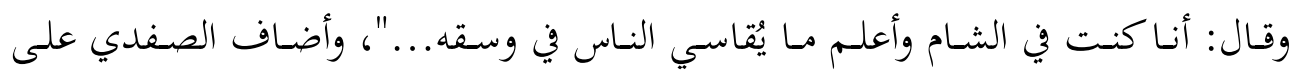

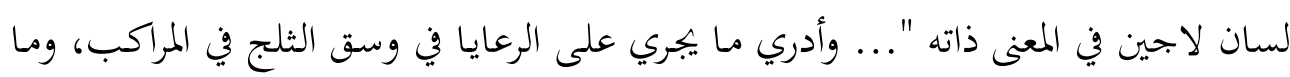
يجدونه من التعب والمغارم والكلف... (76)". وتُعدُ نظرة الصفدي هنا أكثر قرباً من الطبقات التي حُرمت من الإفادة من الثلج، الأمر

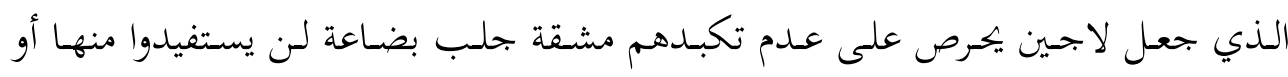




\section{الثلج والثلاجون}

ينتفعوا بها، وقد يكون من المتغيرات السياسية والاقتصادية التي أثرت على نقل الثلج بالسلب ما حدث من جوع وغلاء وذلك من جراء غلاء الأسعار وندرة الأقوات في ظل سلطنة كتبغا - السابق على لاجين المنصوري مباشرة سنة 695هـ - بحيث مات الناس من الجوع وأكل بعضهم أولادهـم وما إلى ذلك (77) وقـد عظُم الوبـاء بحيث مـات الكثيرون، وكانوا يدفنون

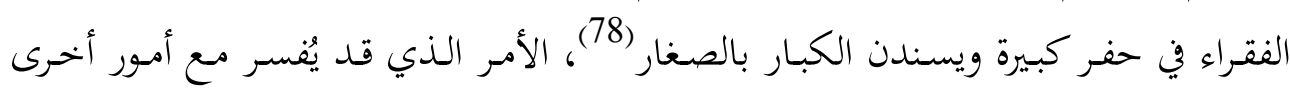
تعرض لها لاجين اضطراره إلى إلغاء جلب الثلج. ناهيك عن أن انتظام جلب الثلج من بـاد الشام إلى مصر لم يكن يتوقف على الهدوء

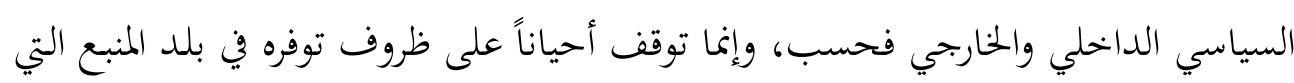

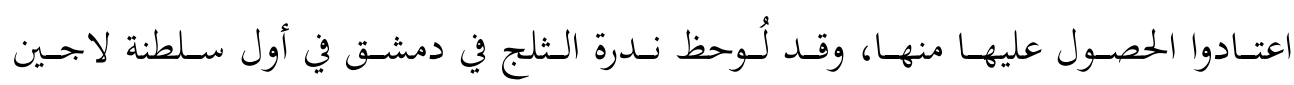
"...وفيها (أي عام 697هـ خلال مدة سلطنة لاجين) قل الثلج بدمشق وغلا سعره، وكان مبدأ ذلك أنه بيع مدة شهر رمضان كل رطل بدرهم، وهو شهر حزيران، واستمر يُباع كل إنل

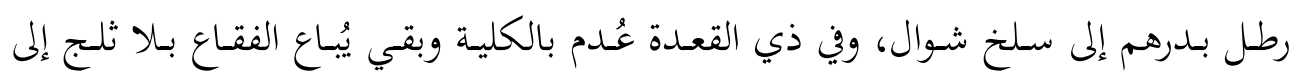

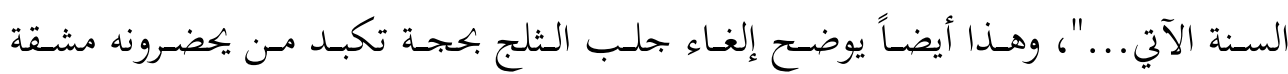
بالغة (79)

ولا يوجـــ في ذلك تعـارض مـع مـا قدمـه العمـري حينمـا أشـار إلى أن الناصـر محمـد قـــ استحدث نقـل الثلج على ظهـور الهجـن مثلمـا زاد في عـدد المراكب مـن ثـاث إلى إحـدى

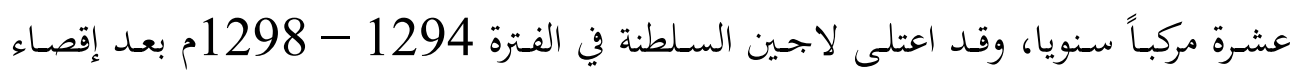
الناصر محمد عن السلطنة وهو الإقصاء الأول له، ثم عاد الناصر إلى عرشه مرة أخرى عام

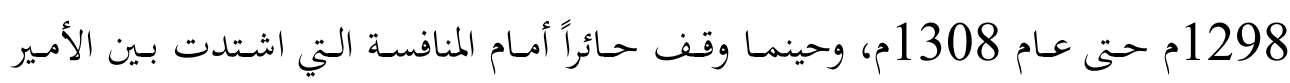
بيبرس الجاشنكير والأمير سلار وقرر اعتزال السلطنة وغادر إلى حصن الكرك، فانتهز بيبرس وحس وفئس

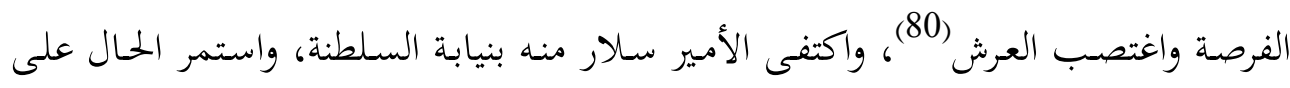

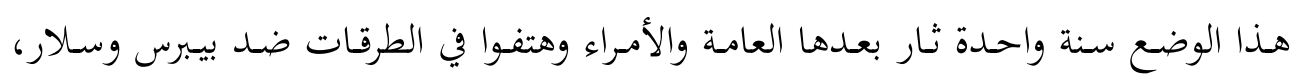
فعاد الناصر إلى عرشه في احتفال شعبي كبير سنة 1309م(181)، وتُعُدُ سلطنة الناصر الثالثة (1309 - 1341م) سلطنته الحقيقية التي دامت حتى وفاته، وهي الفترة التي ظهرت فيها مواهبه وقدراته، وفيها أيضا استُحدث جلب الثلج عن طريق الهجن، وهذا يعني مرة أخرى 
أن جلب الثلج ظل قائماً - على إشارة العمري - منذ سلطنة بيبرس البند قداري وتوقف

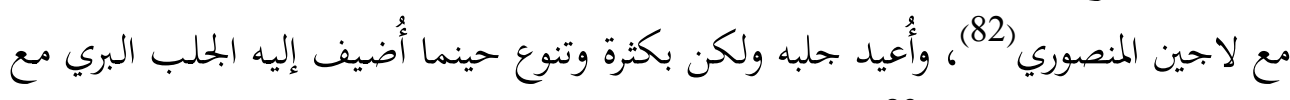
سلطنة الناصر محمد الثالثة(83).

\section{المطات البرية}

اتخــت هجـن الثثلج مـن بعض مراكز البريــ مقــارا مؤقتـة لهـا خـلال موسـم نقـل الثثلج "..وهي لا تعمر بـالهجن (الضمير عائد على مراكز البريد بين بـاد الشـام ومصر) إلا أوان

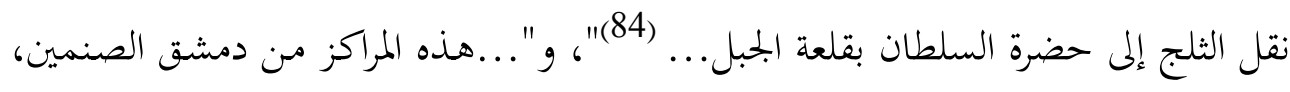
تم منها إلى بانياس ثم منها إلى أربد ثم منها إلى بيسان ثم منها إلى جينين ثم منها إلى قاقون،

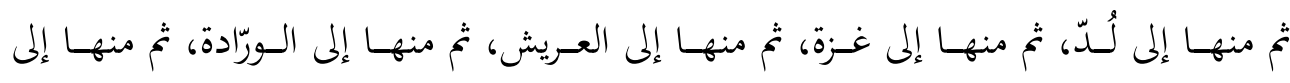
المُطيلب، ثم منها إلى قطيا، ثم منها إلى القصير، ثم منها إلى الصالحية، تم منها إلى بلبيس ثم منها إلى القلعة(85)".

وبدراسة النص السابق في ضوء ما قدمته المصادر الأخرى فإنه يمكن الوقوف على بعض إن

$$
\text { الملحوظات المهمة بخملها فيما يلي: }
$$

1 - استهل العُمري مراكز الانطلاق براً بمدينة دمشق بـالرغم مـن أنه ذكر أن السفن فئن

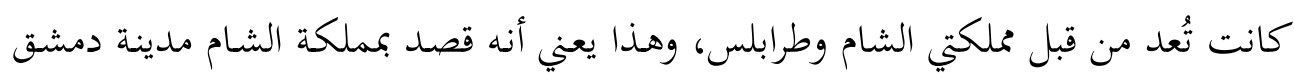

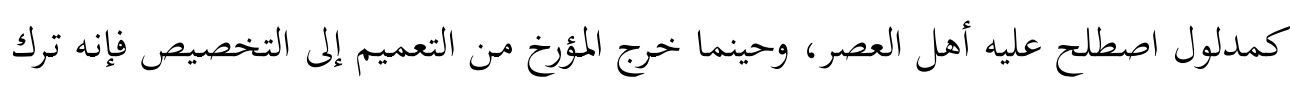
تعبير مملكة الشام إلى مدينة دمشق (86).

2 - تمر هجن الثلج على ما يقرب من 15 محطة بعد انطلاقها من دمشق وصولاً إلى

القلعة، وتتحمل دمشق نفقـة هجـن معطات: الصـنمين وبانياس (87) (استبدلها ابـن شـاهين الظاهري بمدينة طفس) وأربد وبيسان(88) وجنين (89) وقاقون (90) ولد (91) وغزة والعريش (92)،

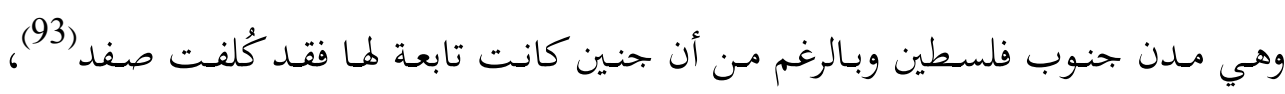

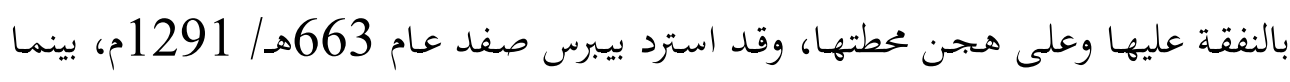
تحملت خزانة مصر - وبخاصة المناخحات السلطانية(94) - كلفة المحطات الأخرى الممثلة في وعني

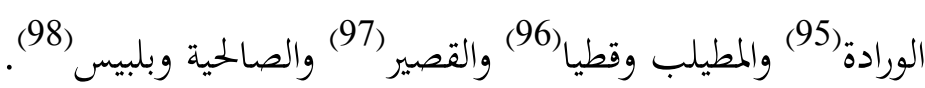
3 - لم تستقر تلك الهجن في تلك المراكز سوى في أوان نقل الثلج التي حسدها بأهنا 
تبدأ من شهر يونيه وصولاً إلى غاية شهر نوفمبر، بحيث استقر في كل حططة 6 هجن: خمسة لحمل الثلج وواحد للهجان. 4 - وصل عدد نقلات الثلج التي تقوم هما تلك الهجن إلى 71 نقلة "... متقارب مدد لهاد

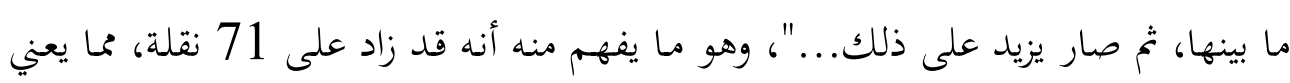

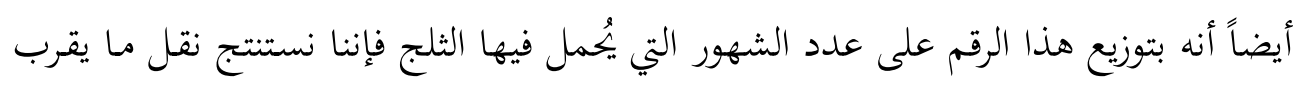

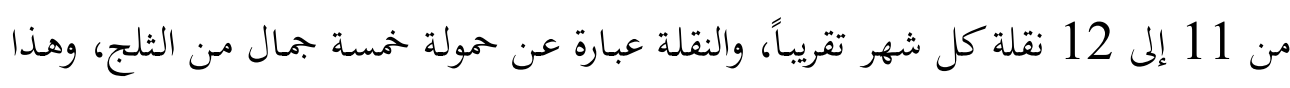

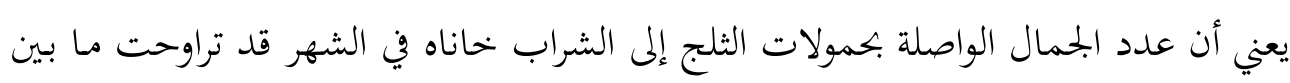

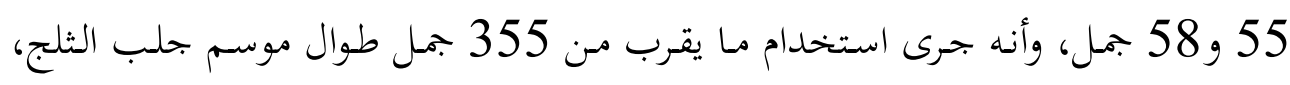

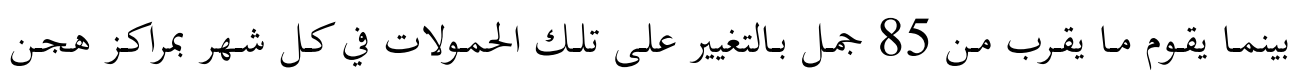

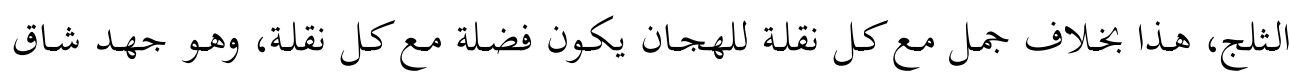

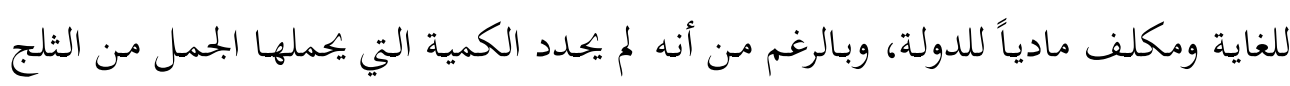
فالمعروف أن الجمل يحمل ما يوازي أربعة أضعاف وزنه.

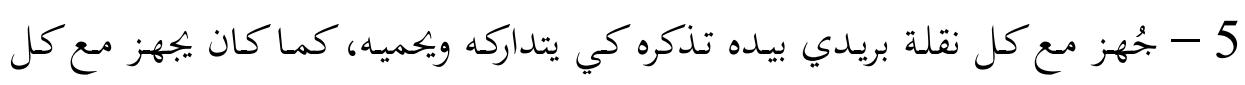

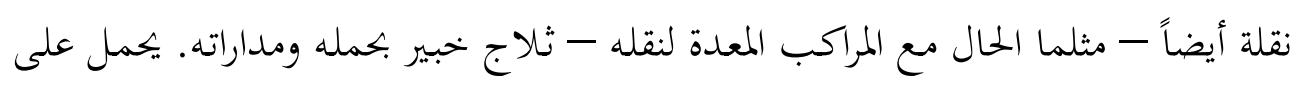
فرس ببريد ثان "...واستقر في وقت أن يُمل الثلاجُ على خيل الولاية".

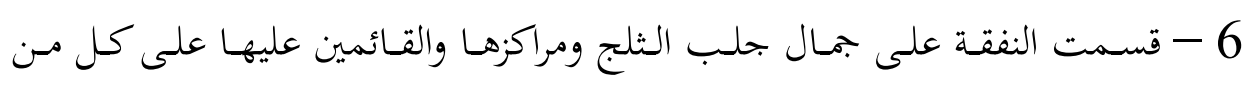
دمشق وصفد والمناخات السلطانية في مصر.

\section{الستخدام الثله في الهصر المملوكي}

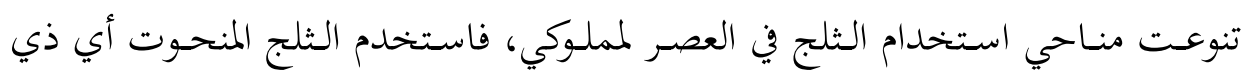

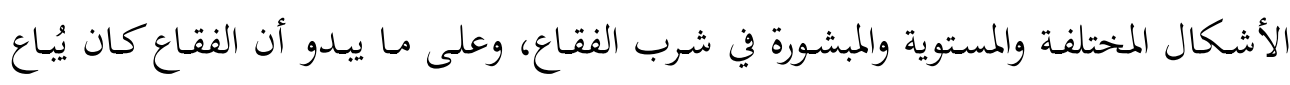

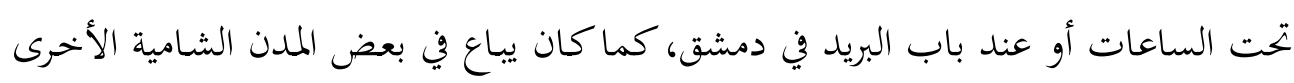

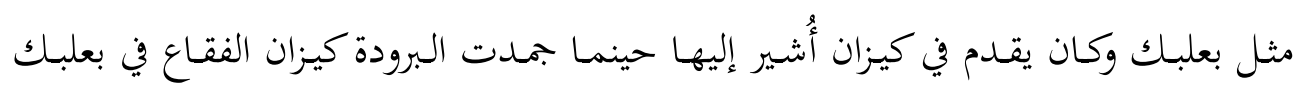

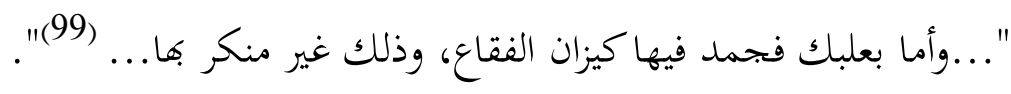

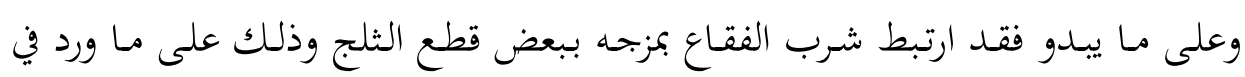

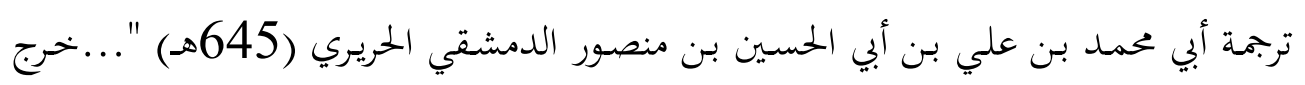


د. حجازي عبد المنعم سليمان

الفلك المسيري يقسم قرية له (والقرية مـن أعمال دمشق على مـا يشير الجزري) وأخـذ منه

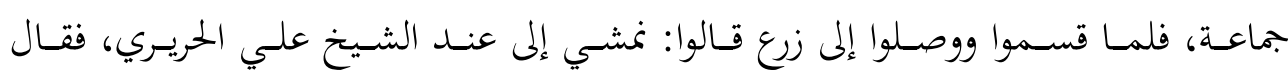
أحسدهم: إن كان صـالحاً يُطعمنـا حلوى سخنه بعسل وسمـن وفستق وسكر، وقال الآخر:

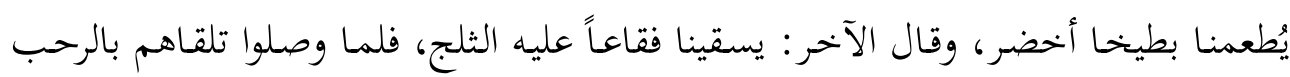
وأحضر شيئاً كثيراً من جملته حلوى كما قال ذلك الرجل فأمر بوضعها بين يدي مشتهيها، تم أحضر بطيخاً آخر وأشار إلى مشتهيه بالأكل، فلما فرغوا نظر إلى صاحب شهوة الفقاع وقال: يا أخي كان عندي تحت الساعات أو باب البريد، ثم صاح يا فلان ادخل، فدخل فقير وعلى رأسه دست فقاع وعليه الثلج منحوت، وقال: بسم الله أشرب... (100)".

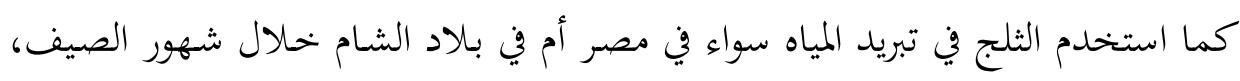

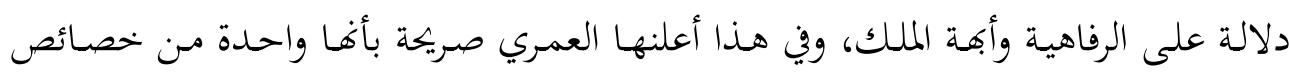
الملكوك الذذين كـانوا يُبـالغون في الرفاهيـة والحـرص على امستلاك الأشياء العزيزة التي لا تتوفر

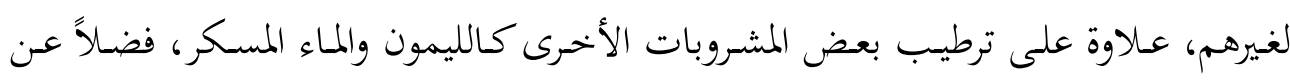
تقديمه مع أنواع معينة مـن الفاكهة وبخاصة العنب بأنواعه في دمشق حتى ارتبطت الضريبة المفروضة على العنب بضريبة الثلج أحيانا، وثمة دلالات كثيرة على وجود رابط يكاد متلازما بين توفر الفواكه والثلج معا في مصر وبلاد الشام بل وبلاد الحرمين الشريفين في موسم الحجج "... وفي العشر الأوسط من ذي القعدة (سنة 732هـ) جهزوا من دمشق إلى المدينة النبوية الشريفة... لمولانا السلطان... ما يلتقوه بها ثلاثة وأربعين حملا، منها ثلاثة عشر حملا فاكهة كمثرى وسفرجل صيفي وتفاح وغير ذلك من أصناف الفواكه والأعناب... وسيروا خلف الثلاجين، وسموا أن يسافروا إلى قارا ويحضروا من صهاريجها جليد الثلج ويسافروا به إلى عقبة وسية أيله يلتقوا به مولانا السلطان.... (101)".

كما استُخدم الثلج للتعذيب وأحياناً للقتل مثلما استخدمت كمادات الثلج لعلاج آلام الرأس والصـداع، إضـافة إلى وضع الثلج على الجحروح الخطيرة النابتـة عن المشـاركة في المعارك

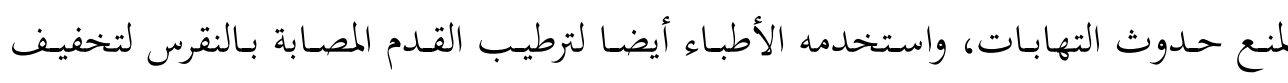

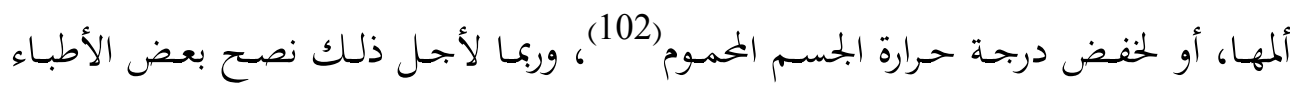
باستخدام أنواع معينة من المشروبات المضاف إليها ثلج لمعالجة أمراض بعينها. 
وأكد ابن الجزري على أن التوت الشامي الأسود المر إذا حُلط بالسكر والثلج فإنه يُعالج

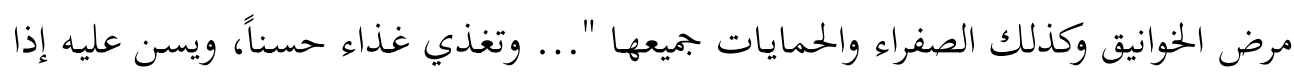

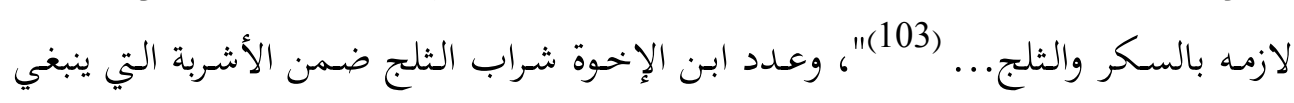

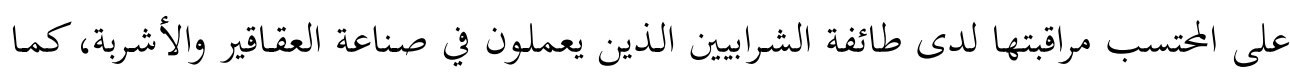
ذكر أكثر من نوع من شراب الليمون (104).

ومن جهة أخرى فإن البلدان التي كان يتساقط عليها الثلج مثل دمشق كان أهلهاب ألها يلهون

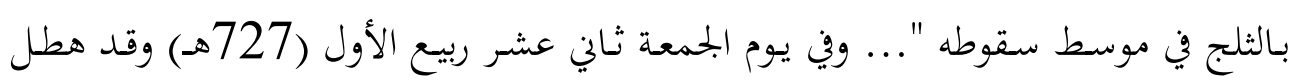

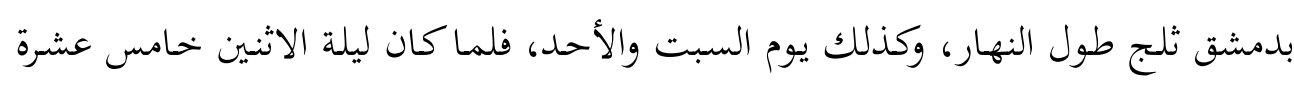

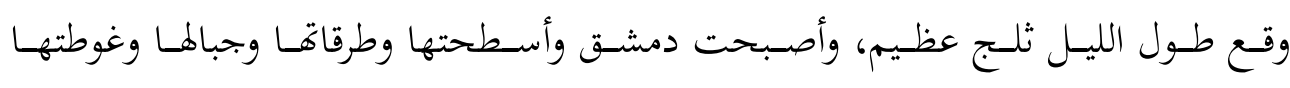

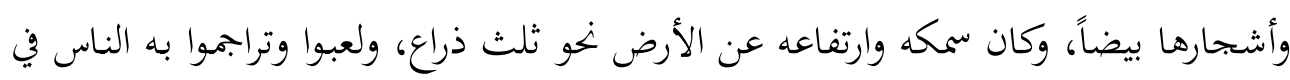

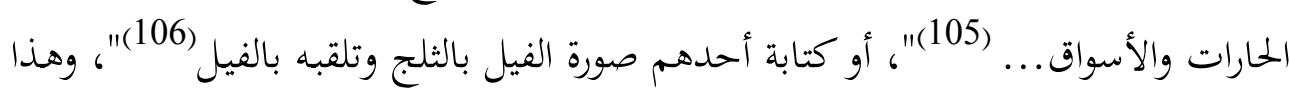
جانب آخر ترفيهي ولكنه لم يتوفر سوى لسكان البلاد التي يسقط عليها الثلج على غرار أغلب المدن الشامية.

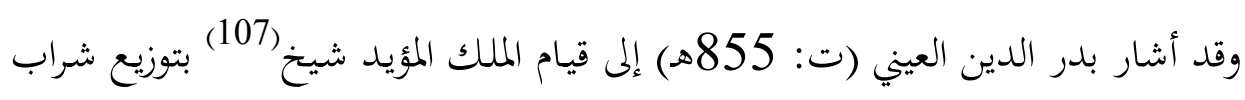

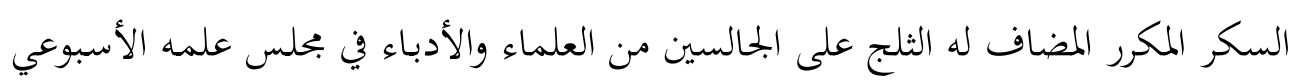

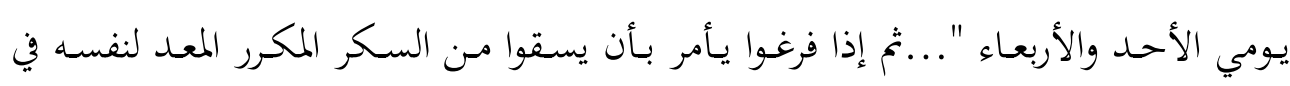

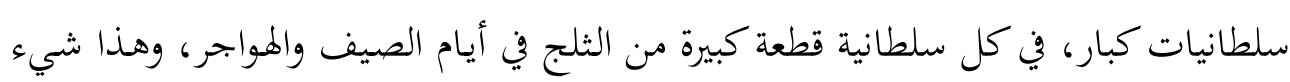

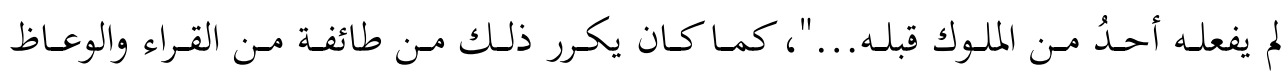

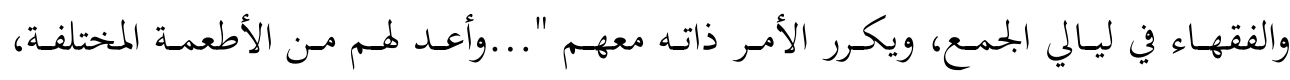

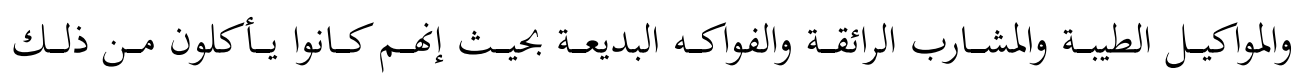
ويحملون... (108)".

\section{الثلج والعلاقات السياسية الفارجية}

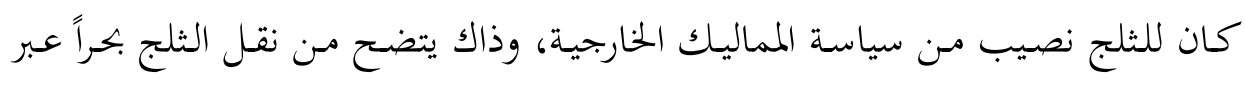

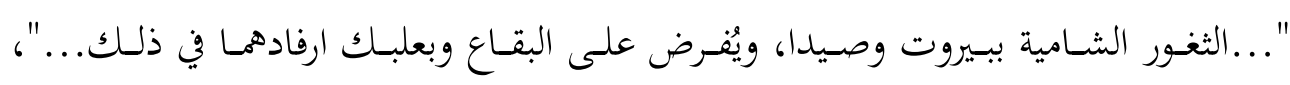

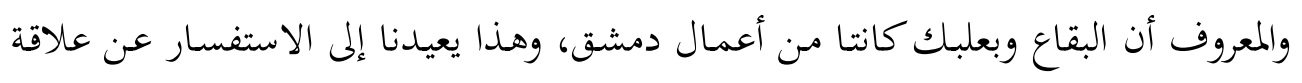




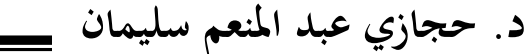

دمشق بتجهيز الثلج المنقول بحراً، حيث يُنقل الثلج بمساعدة من البقاع وبعلبك حتى يصل إلى بيروت وصيدا، ومن هناك يتم شحنه براً إلى دمياط في مصر. وقد أشرفت طرابلس فيما بعد على شحنه إلى مصر على ما أشار ابن فضل الله العمري، بينما استرد الأشرف خليل مدينتا بيروت وصيدا عام 1291م اللتان تشرفان على مراكب الثلج منذ أيام الظاهر بيبرس وربما من قبله أيضاً، وهذا قد يعني أيضاً أن الاتفاقيات والهدن التي عُقدت بين المسلمين والصليبيين الذين يسيطرون على بيروت وصيدا قد تضمنت بعض البنود التي نظمت عدم التعرض للمراكب التي ستحمل الثلج من صيدا وبيروت، وبخاصة أن علاقات بيبرس وغيره من سلاطين المماليك بالصليبيين كانت من منطلق القوة، حتى إنه في تمديد بيبرس لأمير طرابلس - الذي اعتاد محالفة المغول ضد المسلمين - بعث له بهدية من طيور الصسيد والثلج "...فلمـا بلغ السـلطان ذلك سـير إليه (أي إلى أمسير طرابلس) غزلانـاً

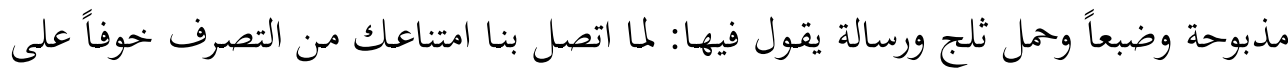
نفسك وهجرانك للصيد الذي هو غاية مرامك بغينا إليك نصيباً من الإجحاف بك وهن والميل

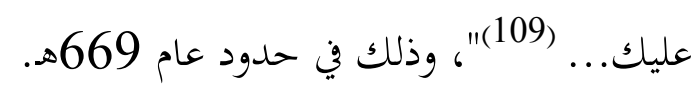
وبالرغم من أن بيبرس كان يتوعد أمير طرابلس بسبب تخلفه عن مقابلته كما جرت عادته

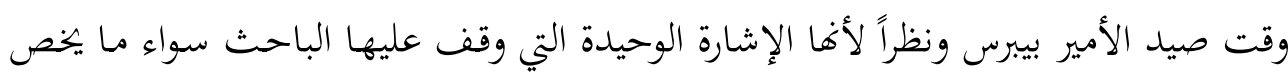
بيبرس أم باقي عصره وعصور السلاطين الذين عاصروا الصليبيين حتى عام 1291م، ولأجل ذلك فإنه يجبـ أن تُعامل تلك الرواية بحذر وبخاصة أن مفضل ابن أبي الفضائل لم يستطرد في تفصيل ما حدث بين الظاهر بيبرس وبين أمير طرابلس. 
ع

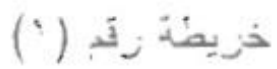

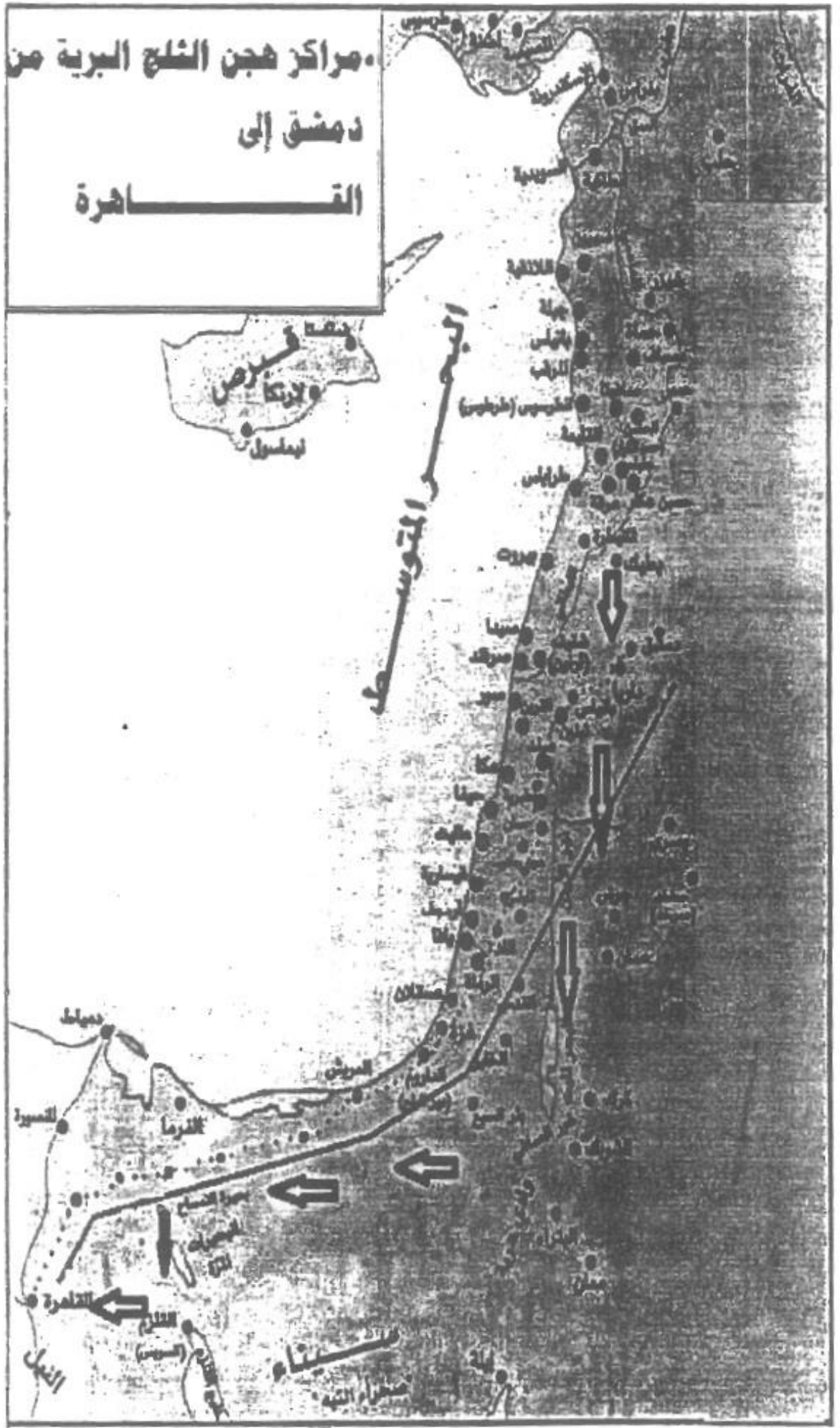


د. حجازي عبد المنعم سليمان ــ

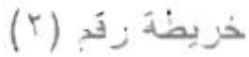

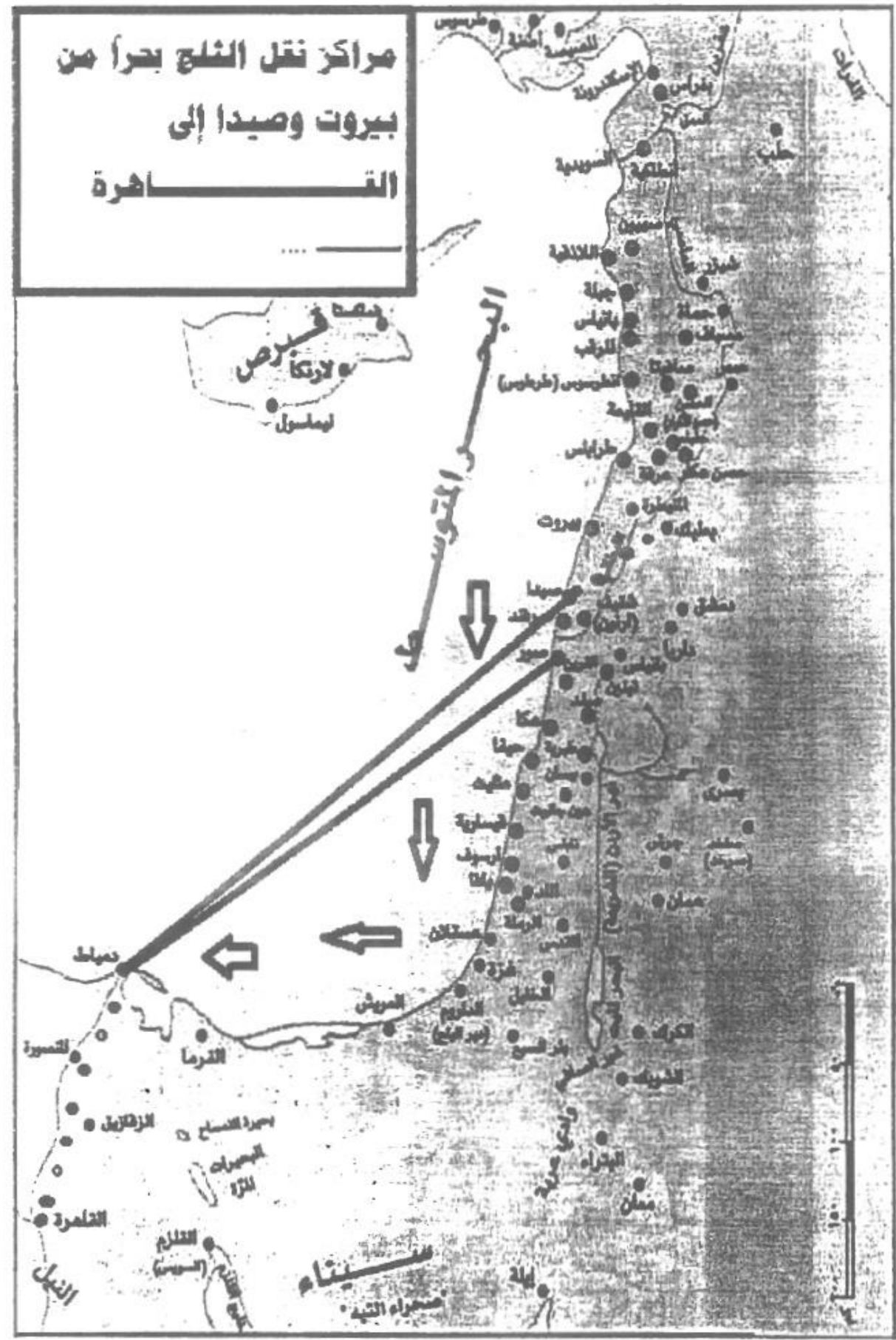


ابـن شـاهين (زن الـــين عبــــ الباسـط بـن خليـل بـن شـاهين الظـاهري الحنفسي

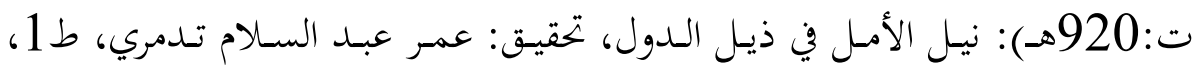

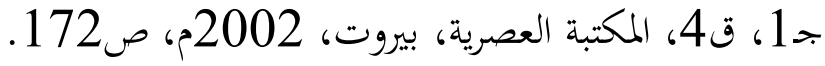

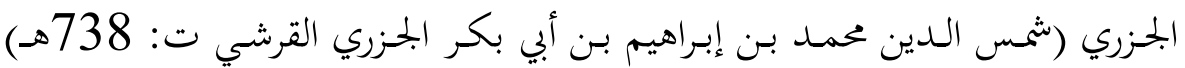

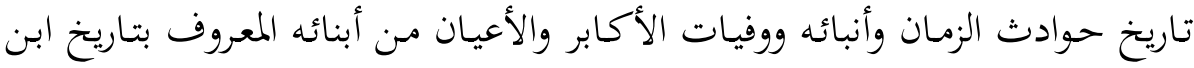

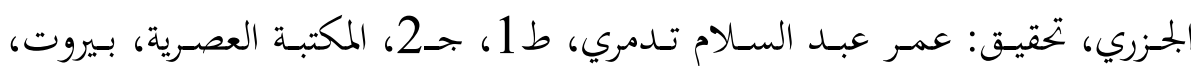

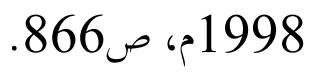

على الرغم من أن مصر لم تكن من البلاد التي يسقط عليها الثلج فإن سقوطه بها

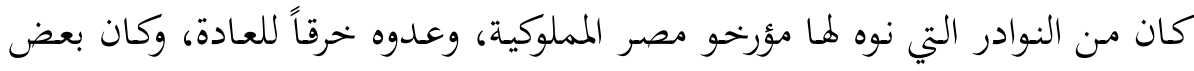

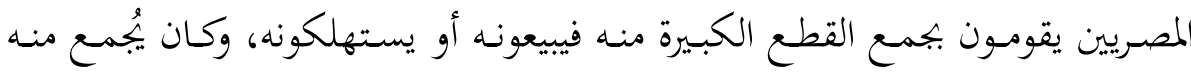

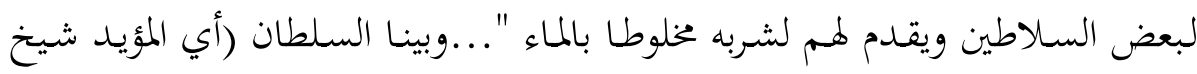

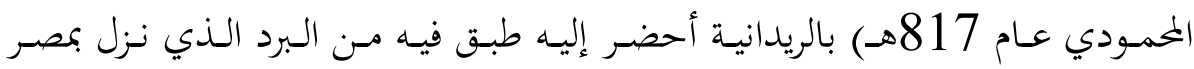

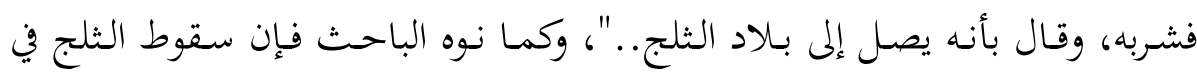
مصر كان من النوادر ومن الأمور قليلة الحدوث واندهش مؤرخو مصر حين حدوثها،

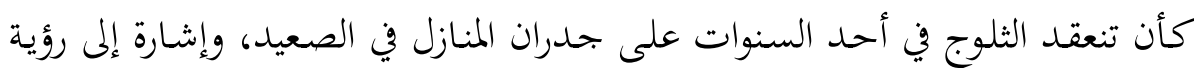

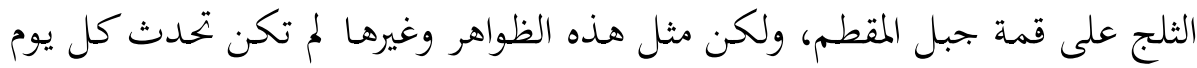

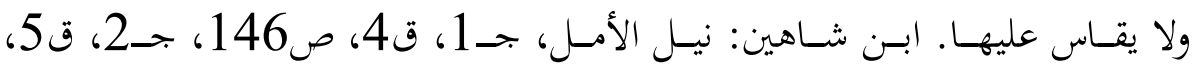

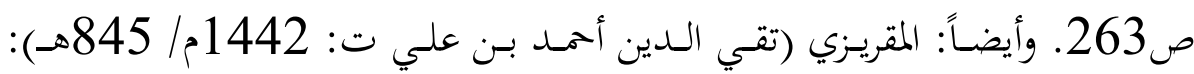

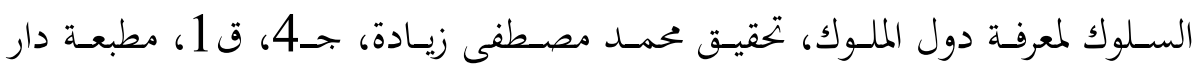

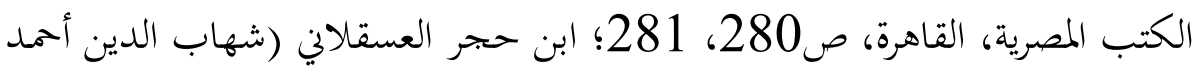

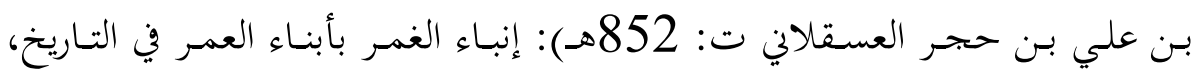

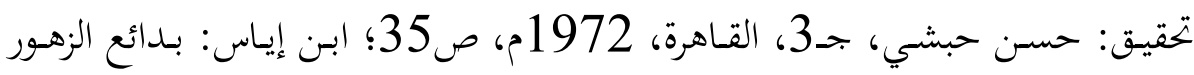

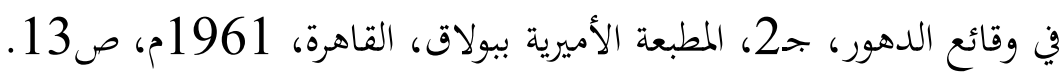

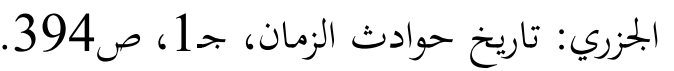

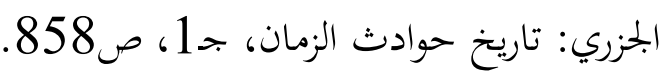


د. حجازي عبد المنعم سليمان سـ

$$
\begin{aligned}
& \text { (6) الجزري: تاريخ حوادث الزمان، ج1، ص866. }
\end{aligned}
$$

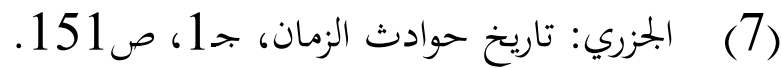

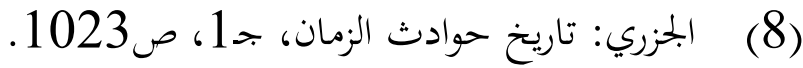

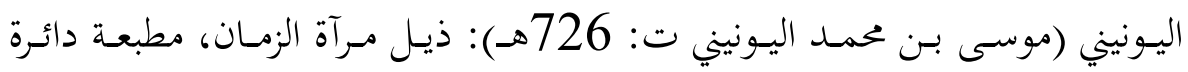

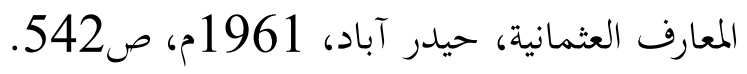

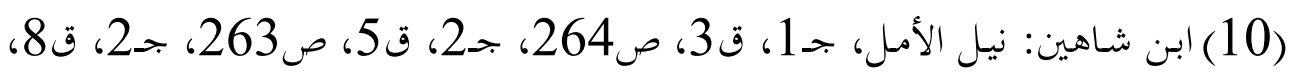

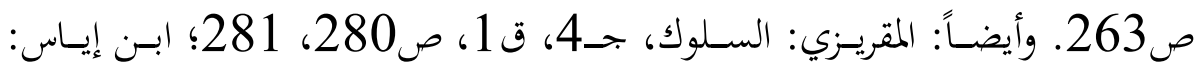

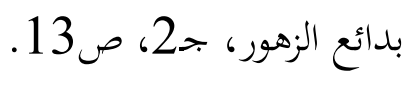

(11) بدر الدين العيني (أبو محمود محمد بن أحمد ت: 855هـ): السيف المهند في سيرة

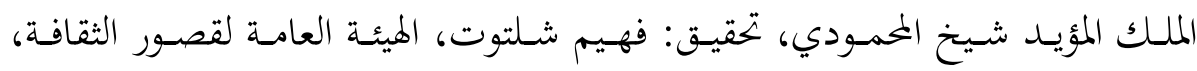
القاهرة، 2003م، ص274، 327. (12) ابن شاهين: نيل الأمل، جـ1، ق3، ص264، ص263، ج2، ق5، ص263، 263، جـ، ق8،

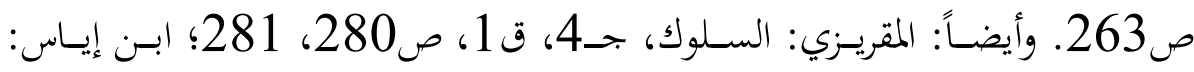

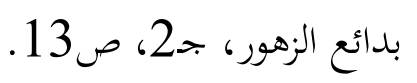

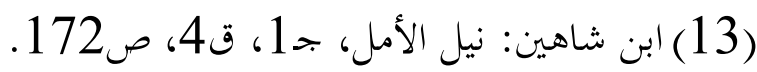
(14) أشار ابن عنين إلى أن البلدان التي يتوفر لها أحد أربع أشياء لا ينبغي أني أن يفارقها أهلها

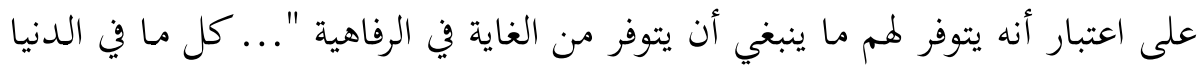

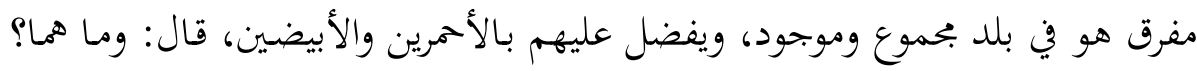

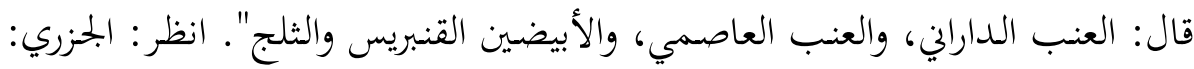

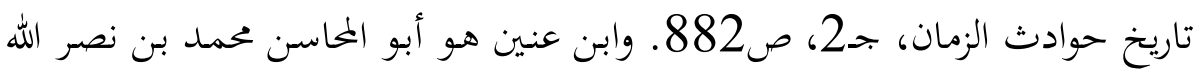

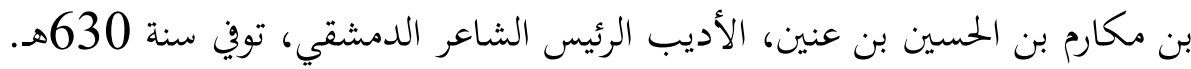

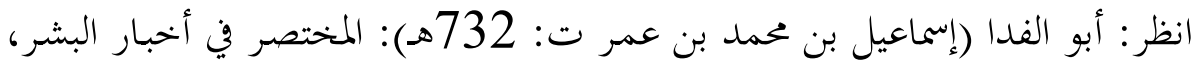

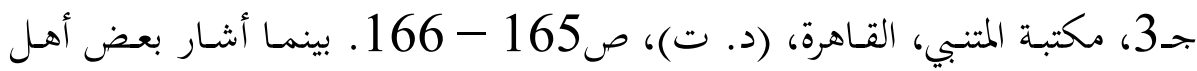

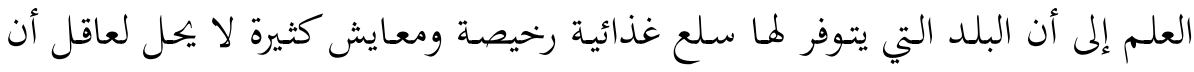

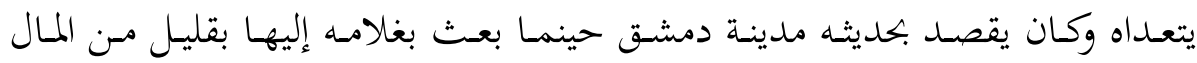

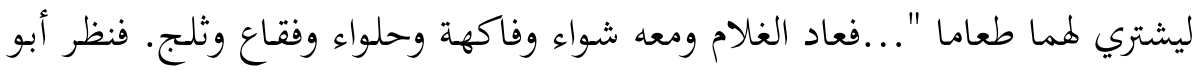


الحكم إلى ما جاء به وقال عند استكثاره: أوجدت أحداً من معارفنا. فقال: لا وإنما

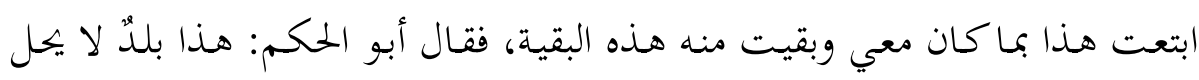

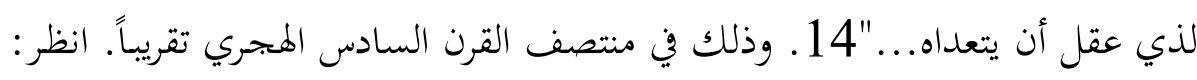

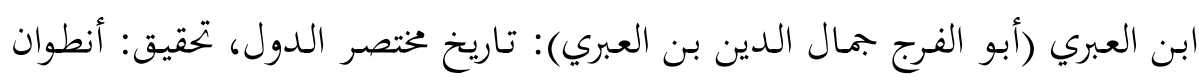

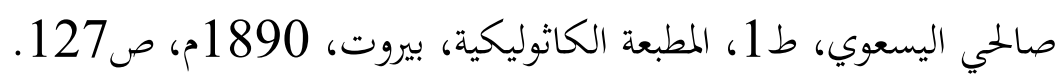

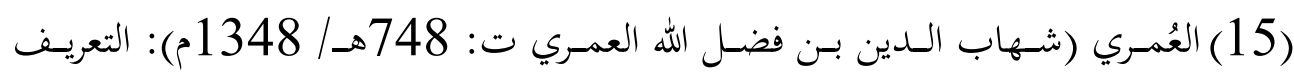

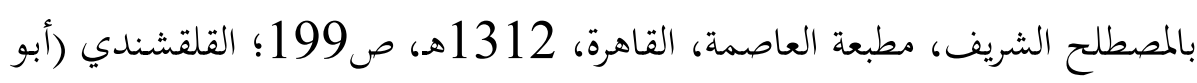

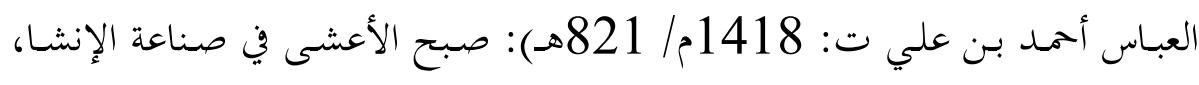

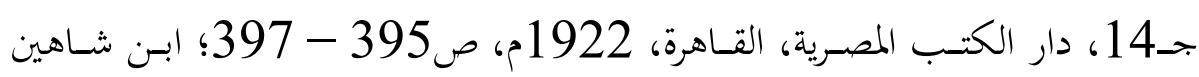

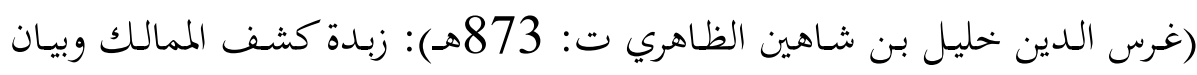

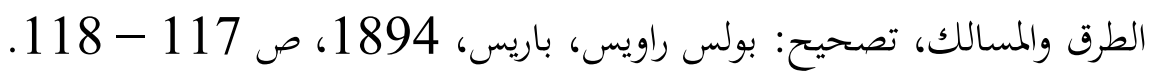

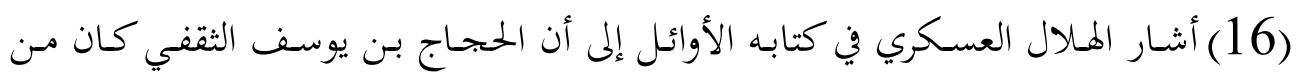

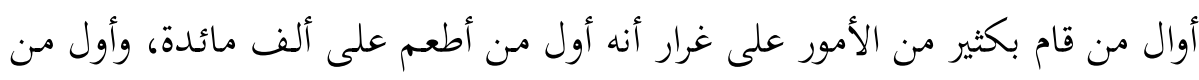

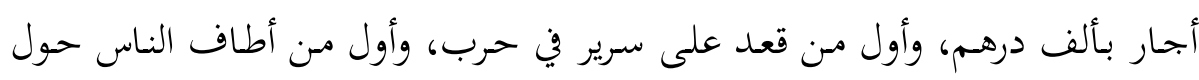

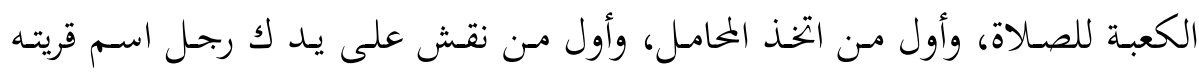

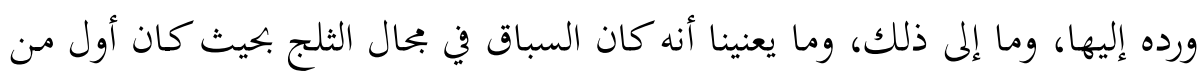

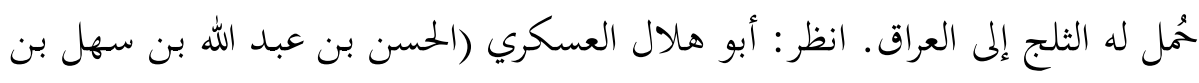

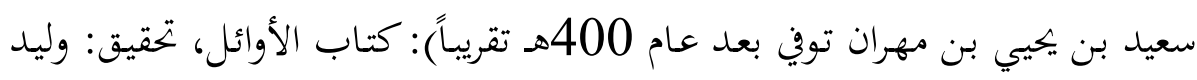

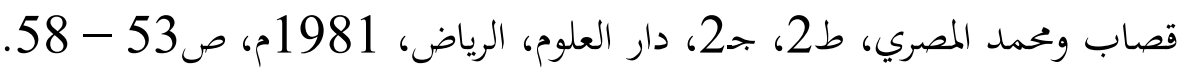

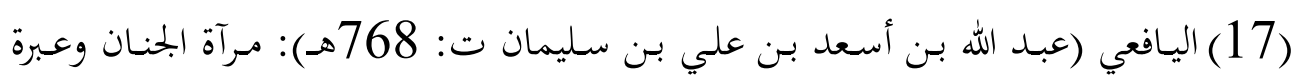

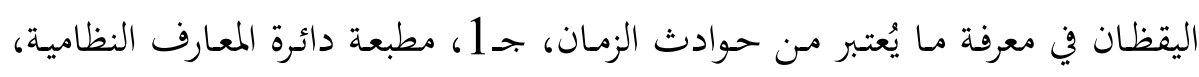

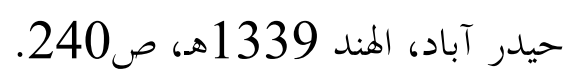

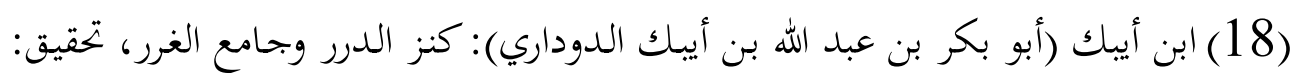

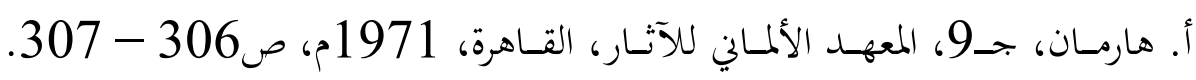

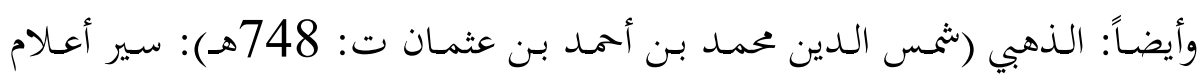

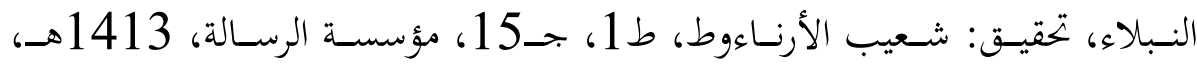
ص170 -171- 
د. حجازي عبد المنعم سليمان

$$
\begin{aligned}
& \text { (19) الذهبي: سير أعلام النبلاء، ج15، ص117 - } 118 .
\end{aligned}
$$

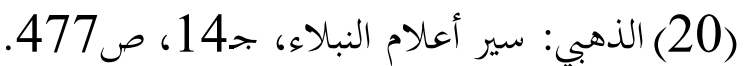

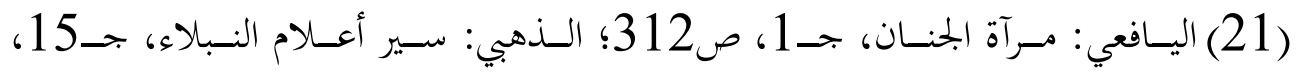

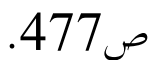

(22) ابـن الجـوزي: المنـتظم في تـاريخ الملـوك والأمسم، ط1، جــ6، دار صـادر، بـيروت،

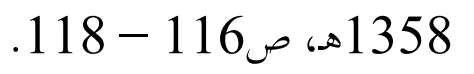

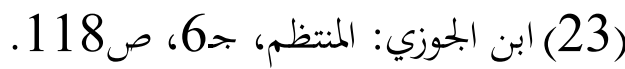

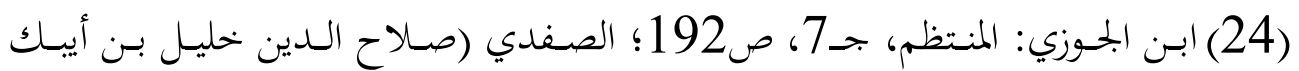

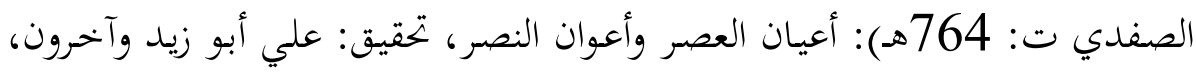

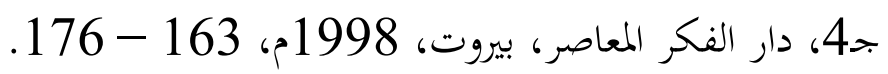

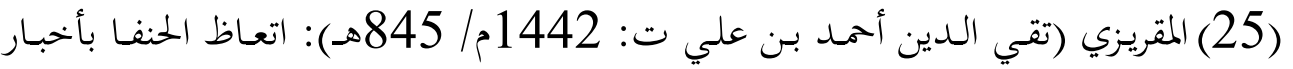

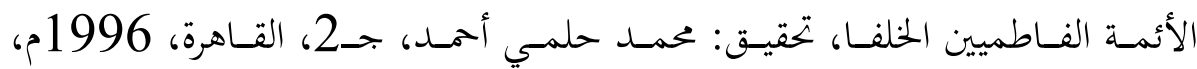

(26) الشرابخانة: هي من البيوتات التي توضع بها الأشربة والسكر والحلوى والعقاقير والفواكه

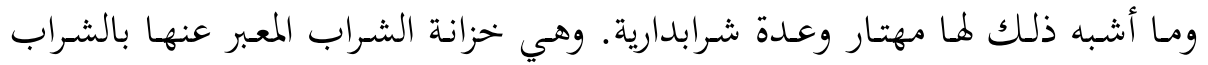

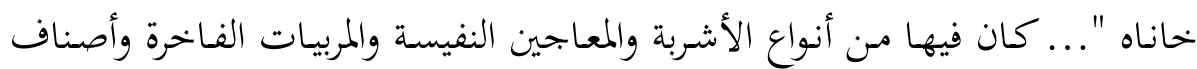

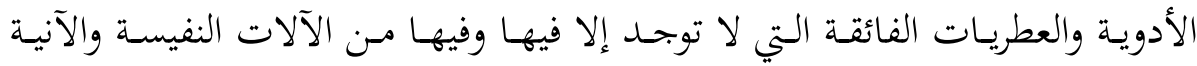

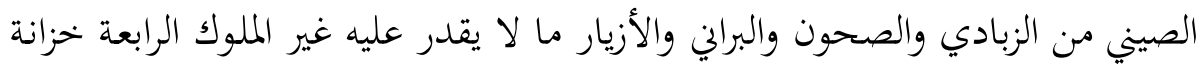

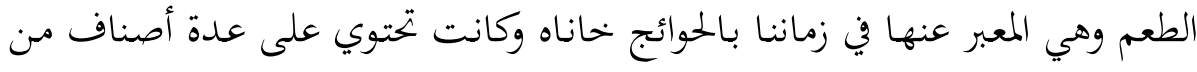

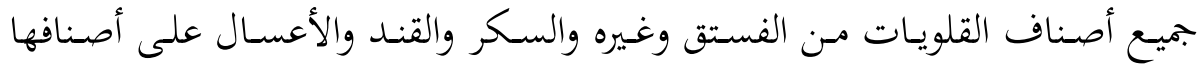

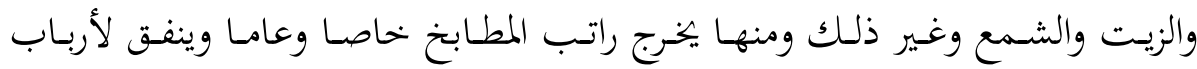

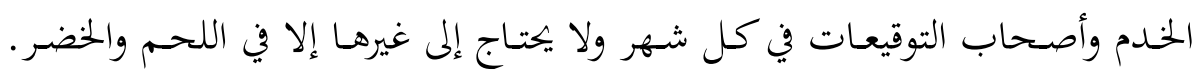

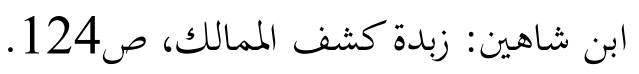

(27) ناصر خسرو (ت: 481 4هـ): سفرنامة، ترجمة: يحيي الخشاب، الهيئة المصرية العامة

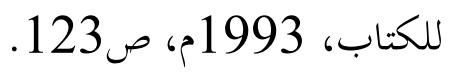

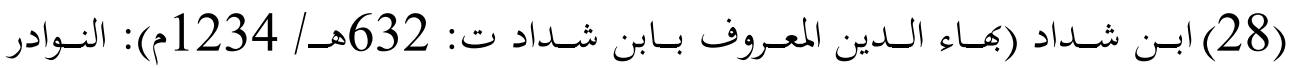

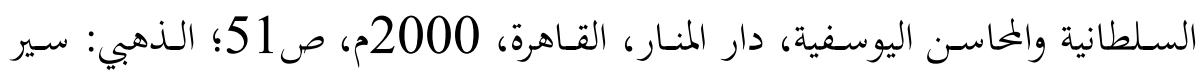




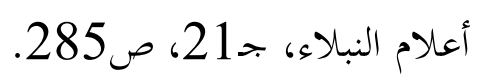

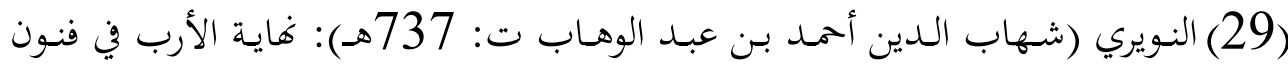

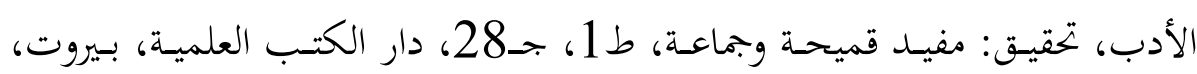

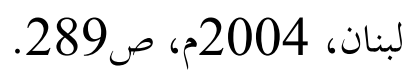

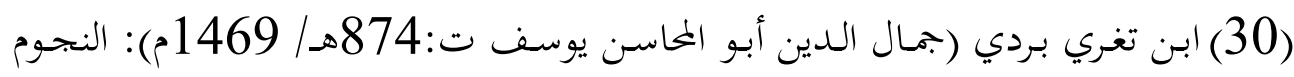

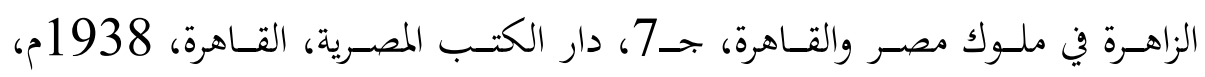
ص ص 361.

(31) ابن خلكان (أبو العباس شمس الدين أحمد بن محمد ت: 681هـ): وفيات الأعيان،

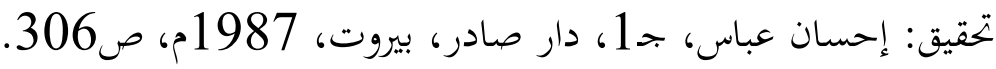

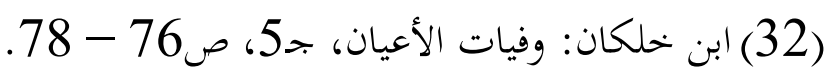

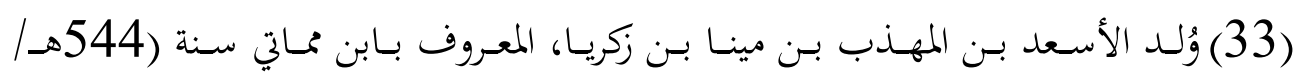

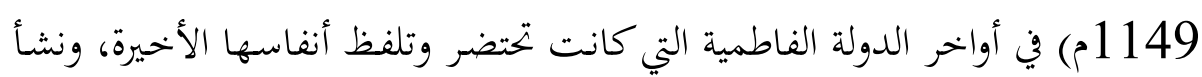

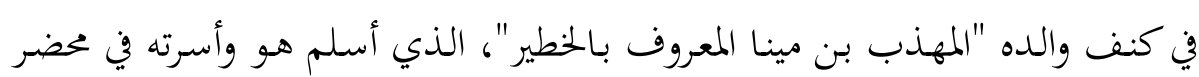
الوزير أسد الدين شيركوه بعهد الناصر صلاح الدين الأيولي.

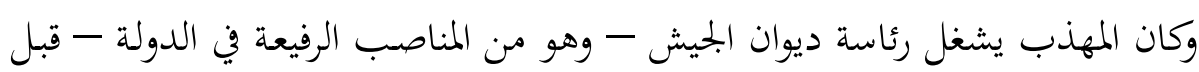

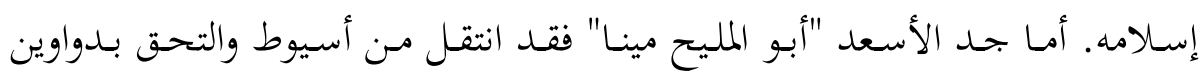

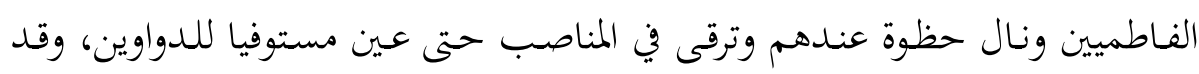

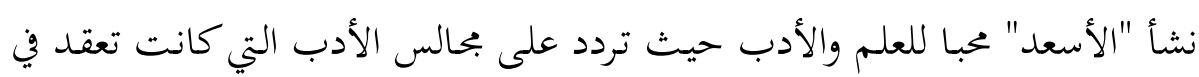

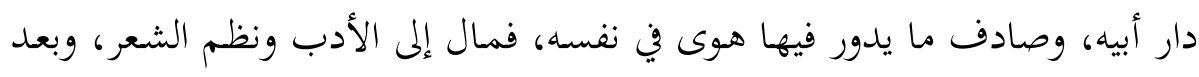

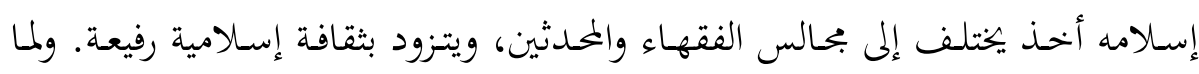

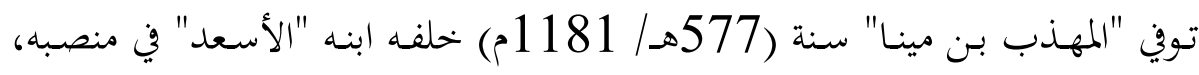

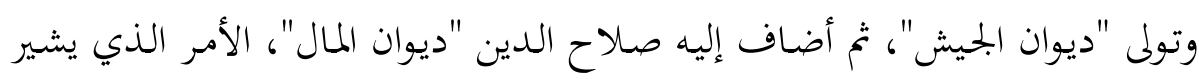

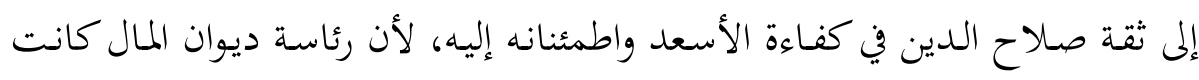
تعد من أهم الوظائف في العصور الإسلامية ومن أجلها شأنا.

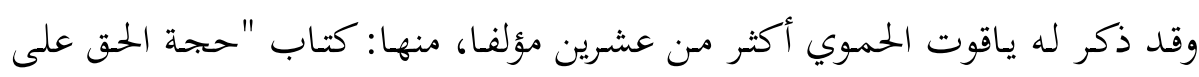

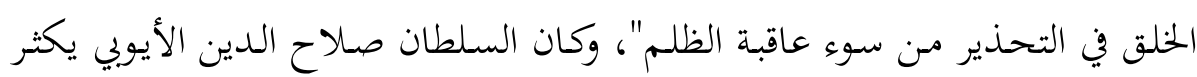




$$
\text { النظر فيه. }
$$

ومن هذه المؤلفات: "نظم السيرة الصلاحية"، أو سيرة صلاح الدين يوسف بن أيوب الذي أهـداه الأسعد للملك الظاهر بن صلاح الدين، وكتاب "الفاشوش في أحكام قراقـوش"، وكتـاب "الشيء بالشيء يـذكر"، وكتـاب "تلقــين اليقـين في الكـلام على لـ حديث بني الإسلام على خمس"، وكتاب "سر الشعر"، وكتاب "علم النثر" وكتاب "باعث الجلد عند حادث الولد" ويعد كتابه "قوانين الدواوين" أهم مـا خلفه الأسعد بـن مماتي حيـث يصف حالة البلاد المصرية خهلال القـرن السـادس الهجـري. انظر في ذلك: يـاقوت الحمـوي (شهاب الدين أبو عبـد الله الحمـوي الرومي ت: 626هـ): معجم الأدباء، إرشاد الأريب إلى معرفة الأديب، تحقيق: إحسان عباس، دار الغرب

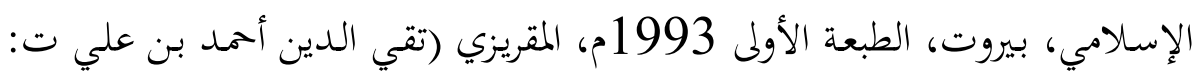

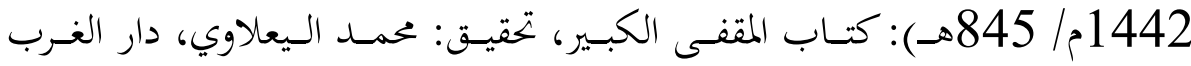
الإسـلامي، بـيروت، ط1، 1991م. وأيضـاً: شـوقي ضـيف: تـاريخ العـربي، عصـر الدول والإمارات، دار المعارف، القاهرة، بدون تاريخ.

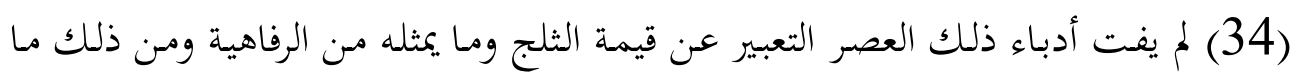
ذكره البعض منه قول أنشده بعض الشعراء للخليفة هارون الرشيد:

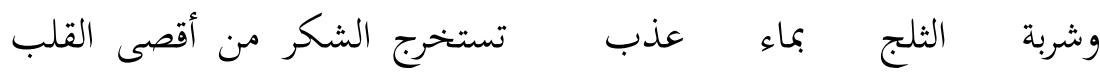
ومنه قول الأسعد بن مماتي عن غازي بن يوسف: وشاهدته في الدست والثلج دونه فقلت: سليمان بن داود والصرح وقول محمد بن المرزبان:

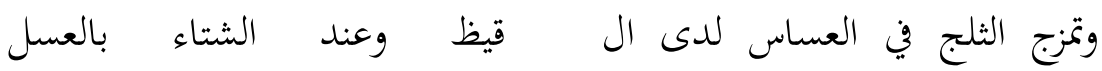
وقول الحسين بن أحمد بن محمد:

الخيش نصف النهار يعجبني والماء بار بارداً وقول عوف بن محلم الخزاعي أحد العلماء والأدباء والرواة:

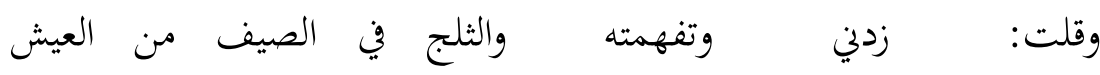
وقال أحدهم وقد وقع بدمشق ثلج عظيم: 
طمت الثلوج على الوهاد مع الرُّبا فالكون يعجب منه وهو مفضفض

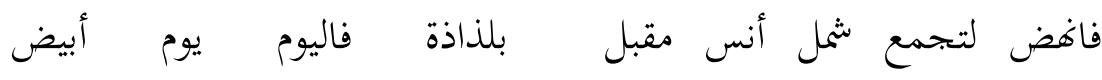

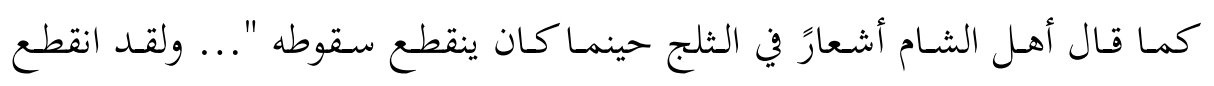
الثلج أيام الخريف، وكانت الحاجة إليه شديدة... فجعلت في ذلك الك عدة مقاطيع....

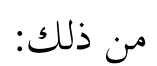
ثلج يا ثلج يا عظيم الصفات أنت عندي من أعظم الحسنات قد قلت لما رأيت الثلج منبسطا بل على الطريق إلى أن ضل سالكها

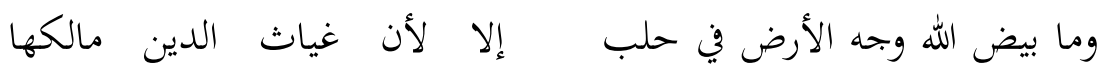
ومن شعر راجح الحلي:

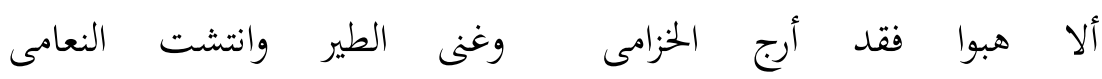

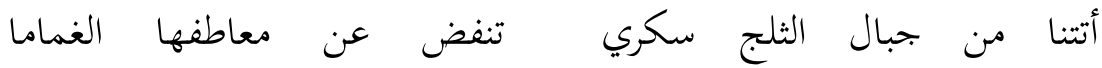

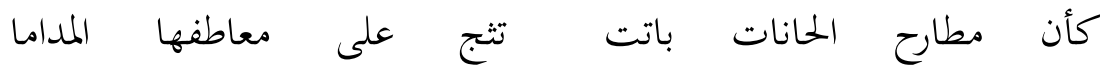
راجح بن إسماعيل بن أبي القاسم الحلي الأسدي: دخل الشام وجال في بلادها ومداح

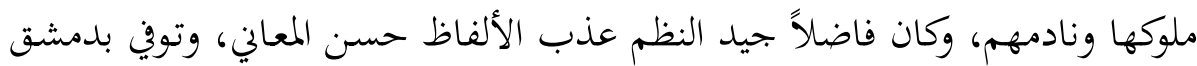

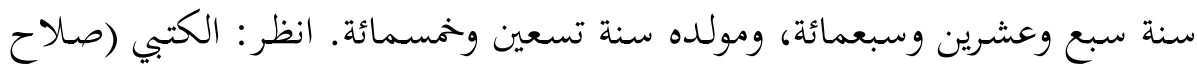

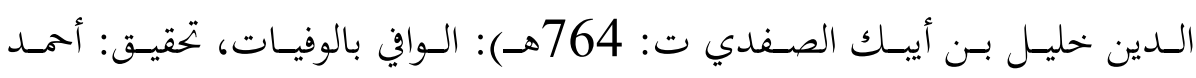

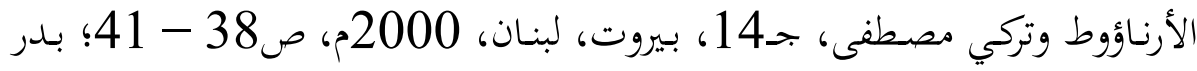

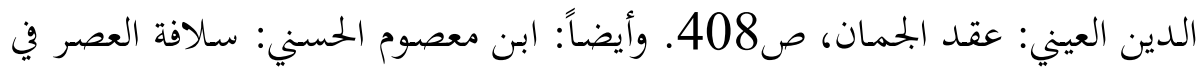
محاسن الشعراء بكل مصر، ص218؛ ابن شداد (عز الدين محمد بن علي بن إبراهيم

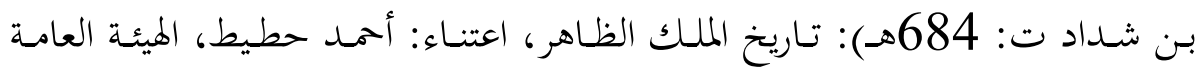

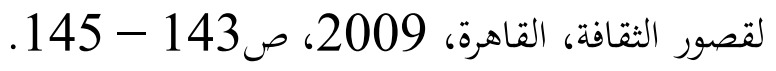

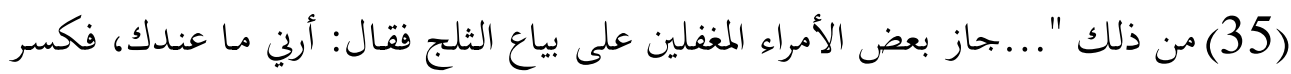

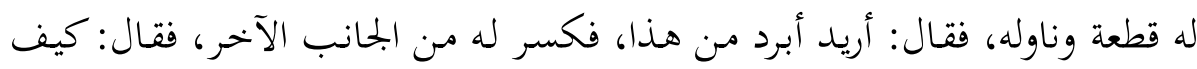

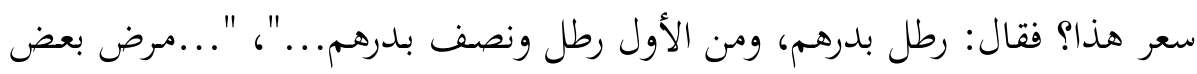

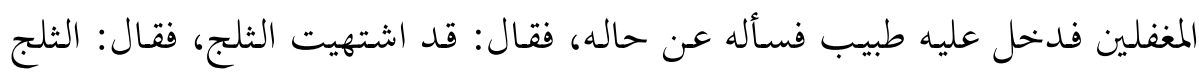




\section{د. حجازي عبد المنعم سليمان}

يزيـد في رطوبتـك فيـقص مـن قوتـك، فقـال: أنـا أمصه وأرمي تفلهه...". انظر : ابـن

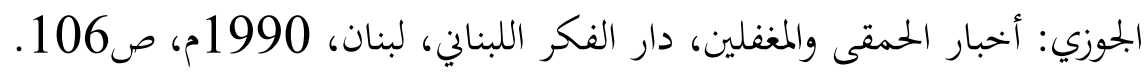

$$
\begin{aligned}
& \text { (36) العمري: التعريف بالمصطلح الشريف، ص199. }
\end{aligned}
$$

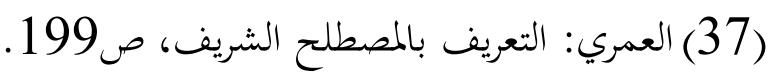

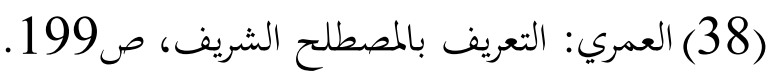

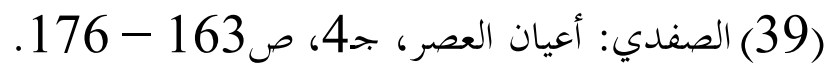

ولم نقف في مصادر تلك الفترة على حيثية اتخاذ القرار على وجهه أكثر شثمولاً، ولكن يمكـن اسـتنطاق بعض تصـرفات منكـوتمر الـذي حجـب السـلطان لاجـين المنصـوري وحكـم باسمـه بوصفها أحسد أو بعض أسباب اتخـاذ ذلك القـرار، فقـد سعى منكـوتر الذي ولي نيابة السلطنة إلى الاستحواذ على عقل لاجين وحجبه عن الخاصة والعامة

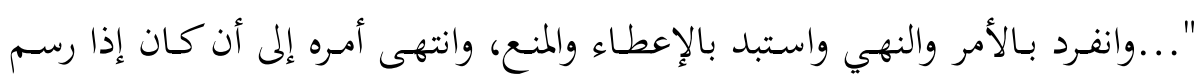

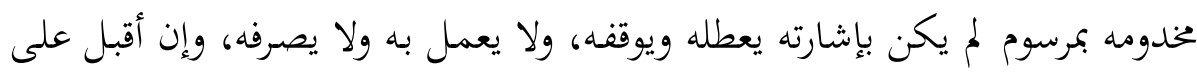
أحد في غيبته أو خص إنسانا بهيبته أبعد ذلك الشخص ودوحره وأقصاه وأخره، وأمر

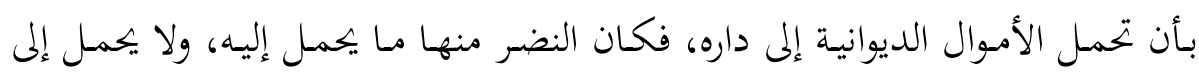

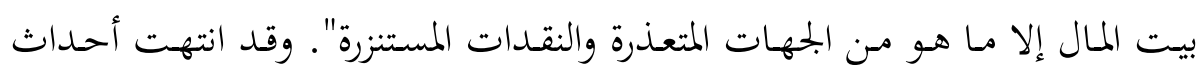
الصـراع على العـش بقتل كل مـن السلطان لجـين ومنكـوتمر وطغتي وكرجي واتفـاق باقي الأمراء على عودة السلطان الناصر محمد للعرش مرة أخرى. انظر: بيبرس المنصوري: مختار الأخبار، تاريخ الدولة الأيوبية ودولة المماليك البحرية حتى سنة

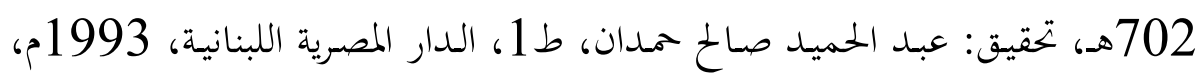
ص105، وأيضا:

Moufazzal Ibn Abil - Fazail, Historire des Sutlan Mamlouks, Texte Arabe et Traduit Francais, Tome II, Par E. Blochet, in Patrologia Orientalis, Vol 20, Paris 1919, pp. 433 - 434.

(40) رئيفة حلواني: البريد في عصر المماليك، رسالة ماجستير غير منشورة، بيروت، ص84؛

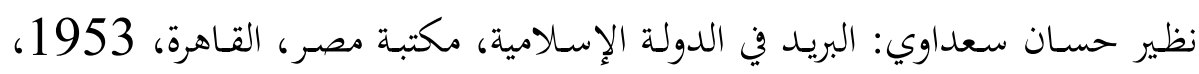
ص 131 - 132 ـ وأيضاً:

Sauvaget, J., La Poste aux chevaux dans l'empire des 


\section{الثلج والثلاجون}

Mamelouks, Librairie d'Amerique et d'orient adrienmaisonneuvem Parise, 1949, pp. 77 - 78.

(41) قارا: مدينة تقع في شمال المملكة العربية السعودية بمنطقة الجموف، وهي عبارة عن

$$
\text { مدينتين (سكاكا - قارا)، وقارا هي الجزء الأصغر منها. }
$$

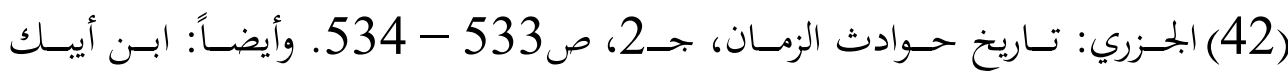

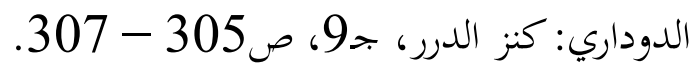

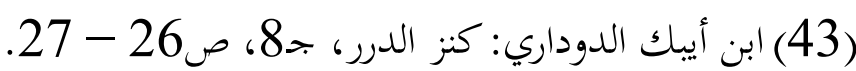

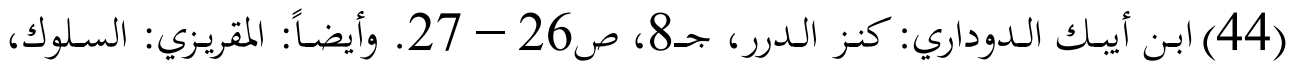

(45) ابن الإخوة (محمد بن محمد بن أحمد القرشي): معالم القربة في أحكام الحسبة، نقله

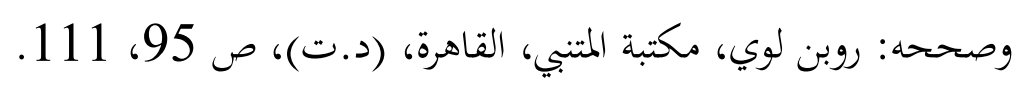

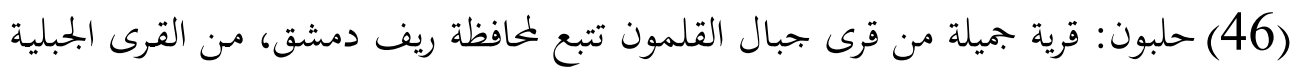

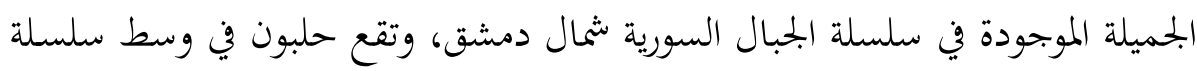

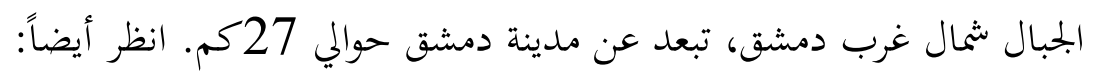

(47) رئيفة حلواني: البريد، ص 84. 84. وأيضاً:

Sauvaget, La Poste aux chevaux dans l'empire des Mamelouks, pp. 77 - 78.

$$
\text { (48) رئيفة حلواني: البريد، ص84. وأيضا: }
$$

Sauvaget, La Poste aux chevaux dans l'empire des Mamelouks, pp. 77 - 78.

$$
\text { (49) الجزري: تاريخ حوادث، ج2، ص177. }
$$

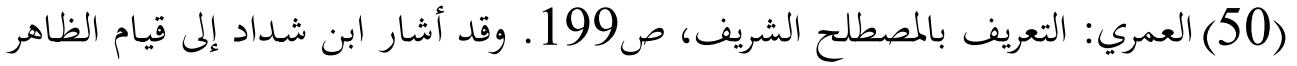

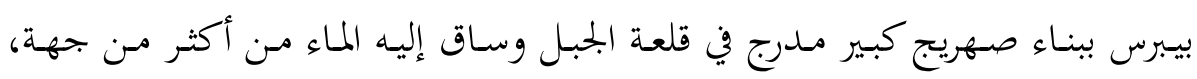

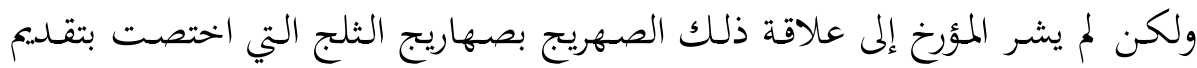

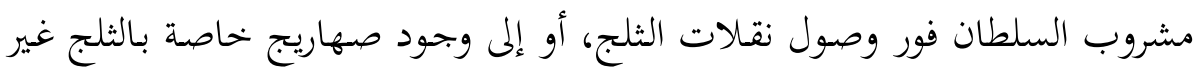
هذا. انظر: ابن شداد: تاريخ الملك الظاهر، ص353.

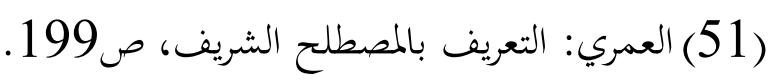

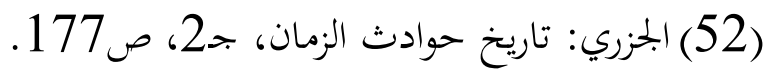


د. حجازي عبد المنعم سليمان

(53) الجزري: تاريخ حوادث الزمان، ج2، ص177.

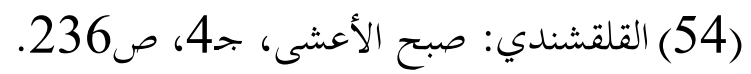

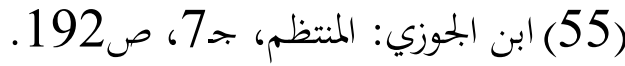

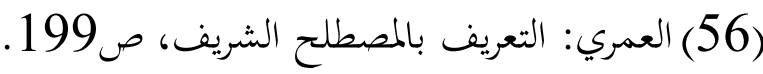

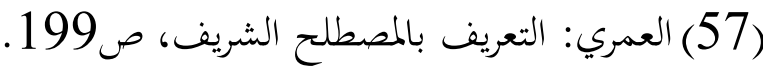

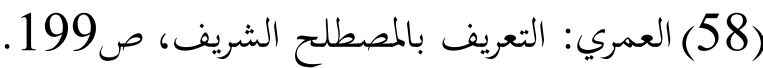
(59) الجزري: تاريخ حوادث الزمان، ج2، صع80 (580.

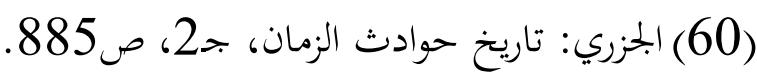

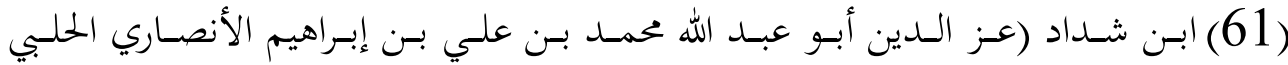

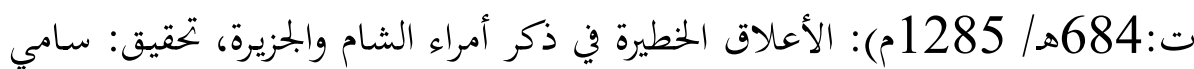

$$
\begin{aligned}
& \text { الدهان، دمشق، 1956م، ص129. } \\
& \text { (62) بدر الدين العيني: عقد الجمان، ص2327. }
\end{aligned}
$$

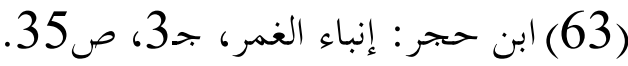

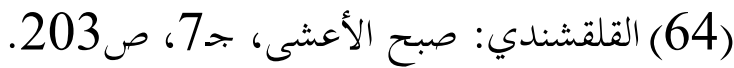

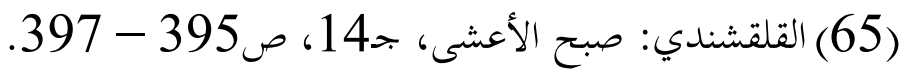

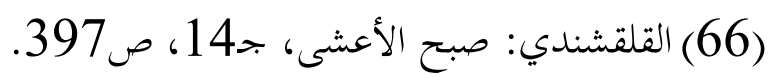

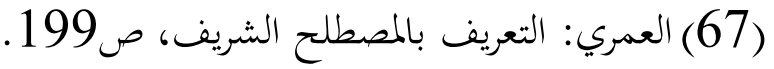

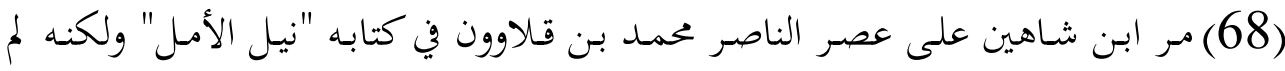

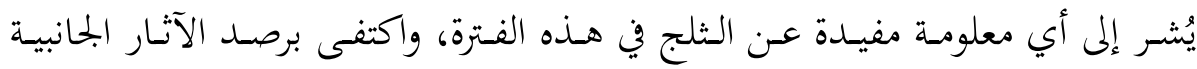

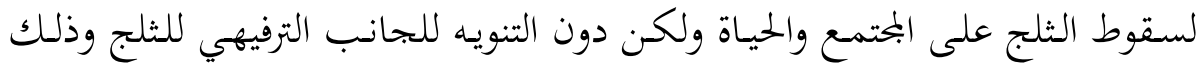

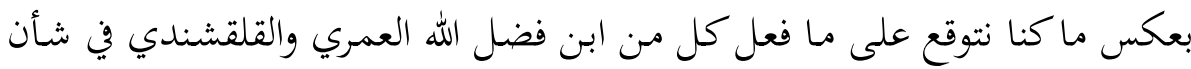

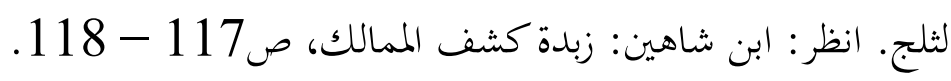
(69) العيني: السيف المهند، ص274. (70) وظيفة شاد الشرابخاناه: هو المسئول عما يرد ويخرج من خزانة الشراب، وعليه مسئولية خطيرة لأنه يجب عليه التأكد من صحة المشروبات وسلامتها.

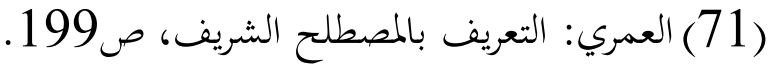




$$
\begin{aligned}
& \text { (72) القلقشندي: صبح الأعشى، ج14، ص395 - } 397 .
\end{aligned}
$$

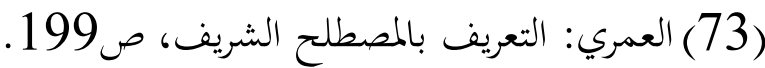

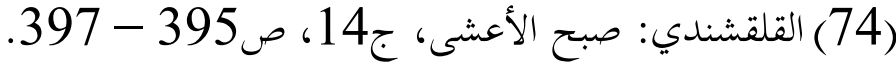

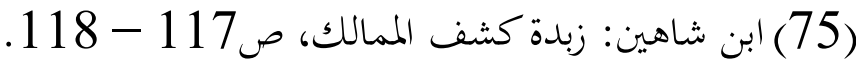

$$
\begin{aligned}
& \text { (76) الصفدي: أعيان العصر، ج4، ص163 ناندان - } 176 .
\end{aligned}
$$

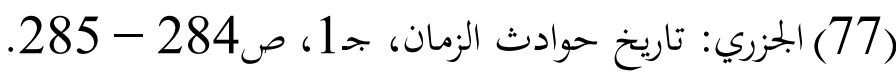

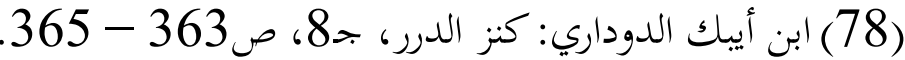

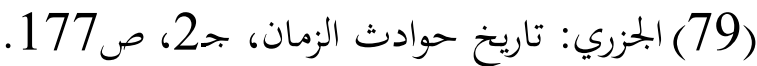

$$
\begin{aligned}
& \text { (80) الصفدي: أعيان العصر، ج4، صوال } 163 \text { - } 176 .
\end{aligned}
$$

(81) لم يتردد الناصر محمد بن قلاوون في الانتقام من كل من بيبرس وسلار، فحبس الأول

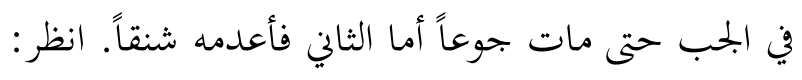

Moufazzal Ibn Abil-Fazail, Histoire des Sultan Mamlouks, Tome III, pp. 531.

$$
\begin{aligned}
& \text { (82) الصفدي: أعيان العصر، ج4، ص163 - } 176 .
\end{aligned}
$$

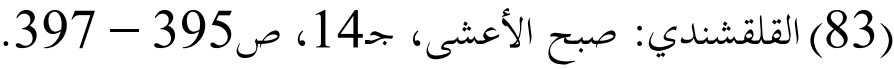

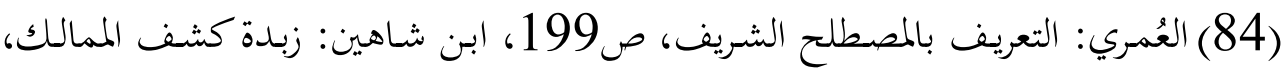

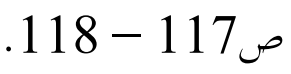

(85) العُمري: التعريف بالمصطلح الشريف، ص199؛ ابن شاهين: زبدة كشف الممالك،

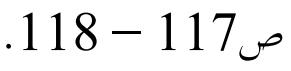

(86) يُشير مفضل ابن أبي الفضائل إلى كل مـن دمشق وصفد والكرك وحماة وحلب والبيرة وطرابلس بوصفها نيابات في ظل سلطنة الناصر محمد بن قلاوون الثانية "... كان سلار

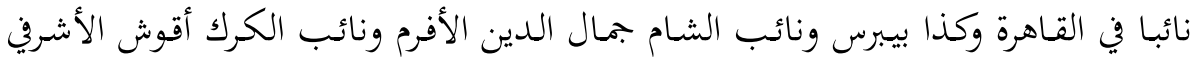
ونائب الشوبك قبجق ونائب حماة الأمير زين الدين كتبغا ونائب حلب الأمير قراسنقر ونائب البيرة سيف الدين طوغان ونائب طرابلس سيف الدين قطلبك ونائب صفد سيف

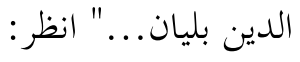

Moufazzal Ibn Abil- Fazail, Histoire des Sultan Mamlouks, Tome III, pp. 531.

(87) هي بلدة صغيرة ذات أشجار مضض وغيرها، تقع على بعد مرحلتين من دمشق ولها حصن 


\section{د. حجازي عبد المنعم سليمان}

منيع. انظر: القرماني (أحمد بن يوسف القرماني ت: 1019هـ): أخبار الدول وآثار الأول

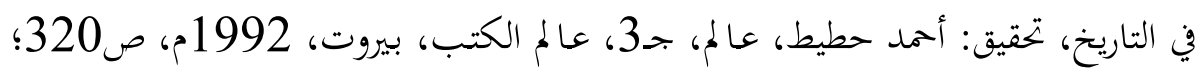

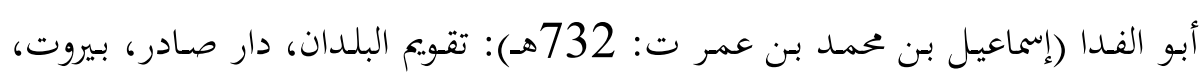
248 1830

(88) بيسان: بالفتح ثم السكون وسين مهملة ونون. مدينة بالأردن بالغور الشامي، ويقال: هي

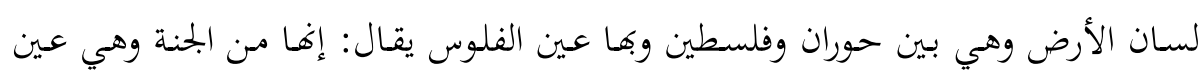

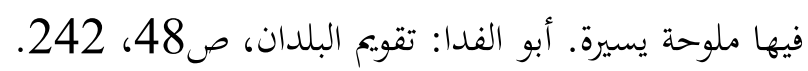

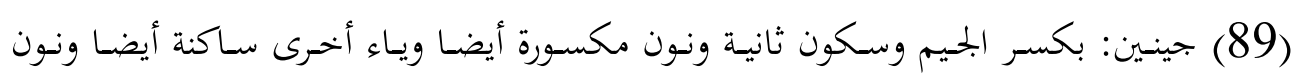

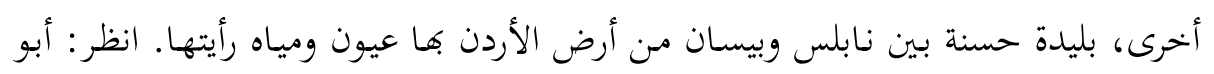

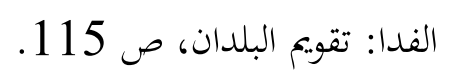
(90) قاقون: بعد القـاف الثانية واو ساكنة ونون: حصن بنفلسطين قرب الرملة وقيل: هو مـن

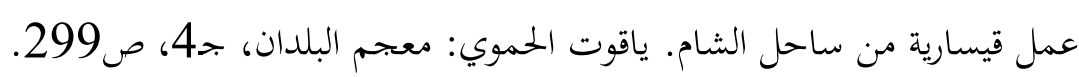

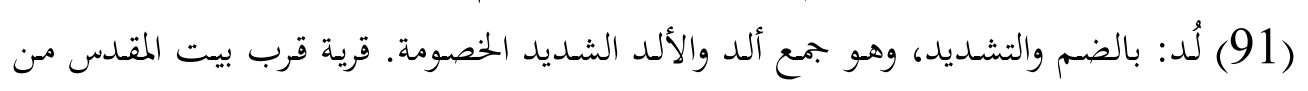
نواحي فلسطين ويقول عنها أبو الفـدا بأها على شوط فرس من مد مدينة الرملة. أبو الفـدا:

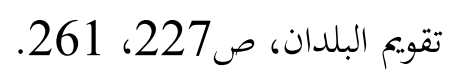

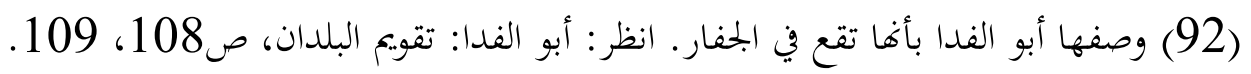

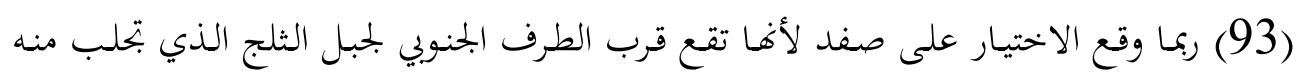

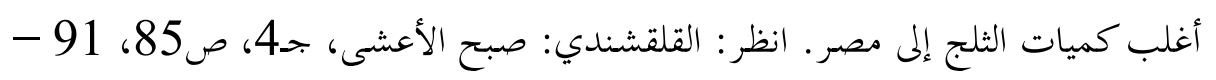

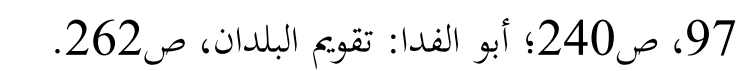

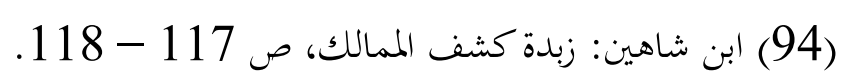
وقد أشار ابن شاهين في حديثه عن الاصطبلات السلطانية إلى اشتمالها على المناخ الذي به الجمال البخاتي الذي يحوي الجمال النفر فهو مضاف إلى الاصطبلات الشريفة، وكذلك الدين

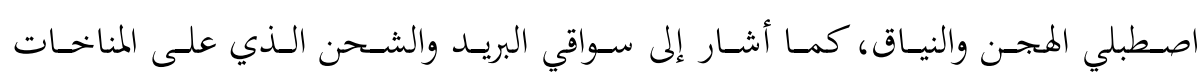

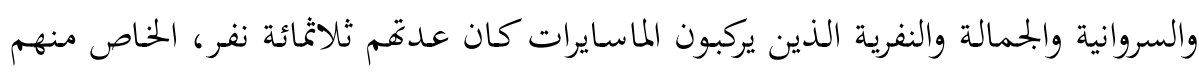

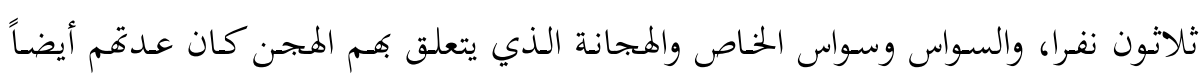

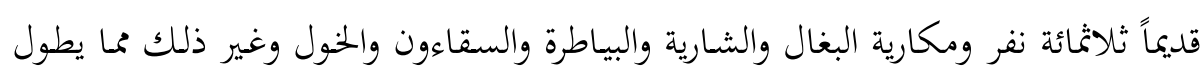

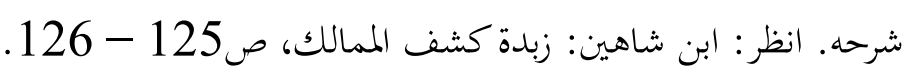
(95) تبلغ المسافة من الورادة إلى مدينة العريش ما يقرب من ثلاثة فراسخ. 
(96) يُشير أبو الفدا إلى قطيا (أو قطية) والورادة بوصفهما من البلدان الواقعة داخل حدود مصر

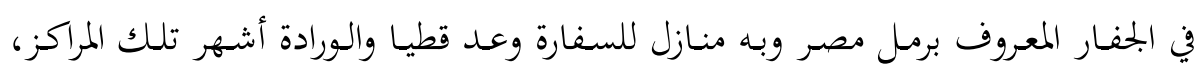

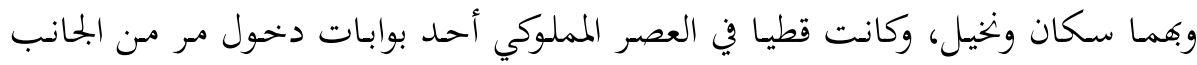

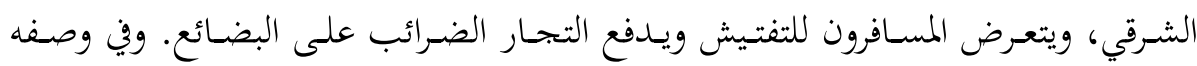

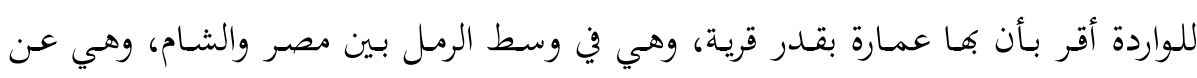

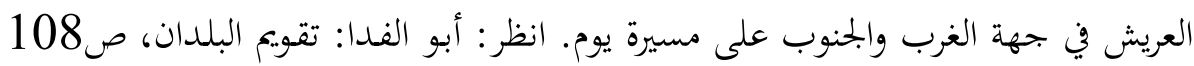

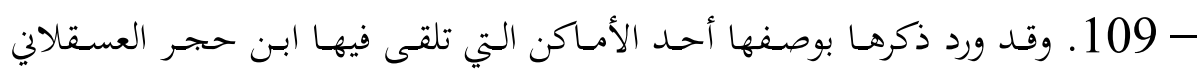
تعليمـه وذكر بعـدها غـزة ونـابلس والعريش ولكنـه ذكرهـا على الشـكل التـالي: "قطيـة".

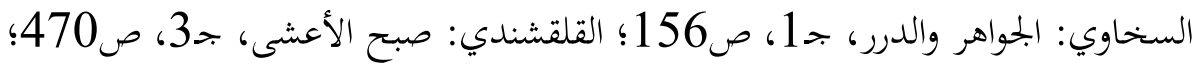

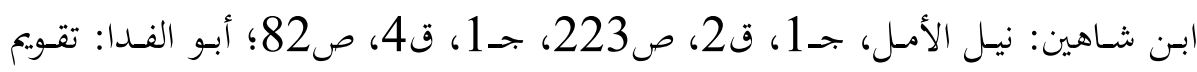

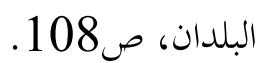

(97) القصير موضع قريب عيذاب بينه وبين قوص قصبة الصعيد خمسة أيام، وبينه وبين عيذاب

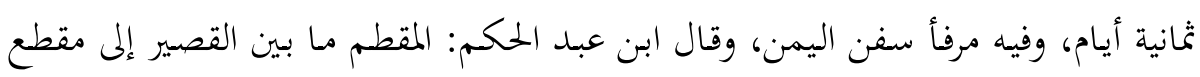

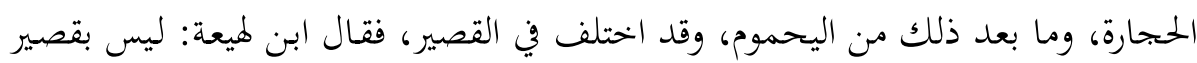
موسى عليه السلام ولكنه قصير موسى الساحر وقال المفضل بن فضالة: عن أبيه قال:

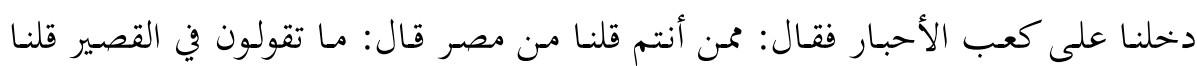
قصير موسى، فقال: ليس بقصير موسى، ولكنه قصير عزيز مصر، وكان إذا جرى النيل يتزفع فيه، وعلى ذلك فإنه مقـد مـ الجبل إلى البحر . انظر : ياقوت الحموي: معجـم

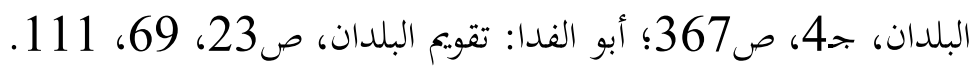

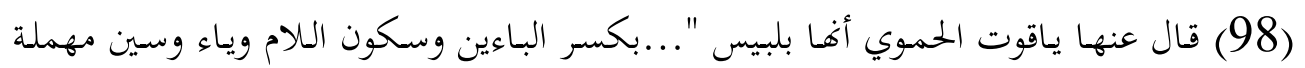

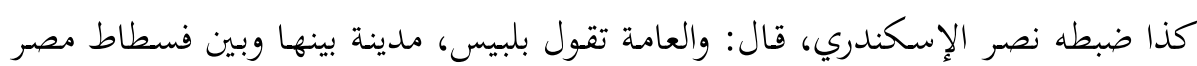

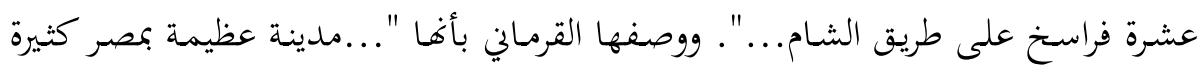

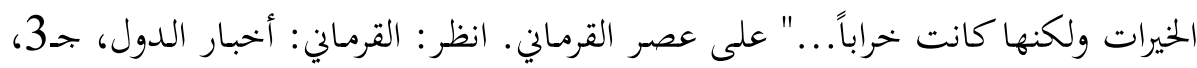
ص322.

(99) اليونيني: ذيل مرآة الزمان، 542. (100) ابن العماد الحنبلي: شذرات الذهب في أخبار من ذهب، تحقيق: محمد الأرناووط، ط1 1ه،

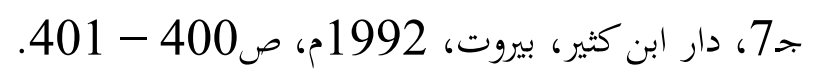

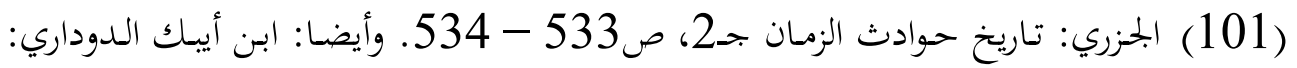


د. حجازي عبد المنعم سليمان

$$
\begin{aligned}
& \text { كنز الدرر، ج9، ص305 - 307. } \\
& \text { (102) ابن الجوزي: المنتظم، ج5، } 121 \text { - } 122 .
\end{aligned}
$$

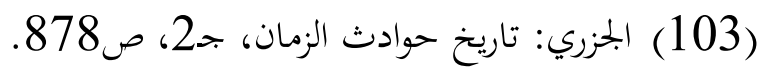

$$
\begin{aligned}
& \text { (104) ابن الإخوة: معالم القربة، صناريخ النمان، } 116 \text { - } 117 .
\end{aligned}
$$

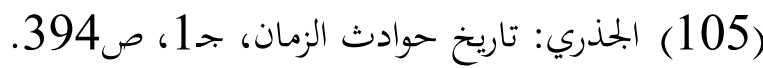

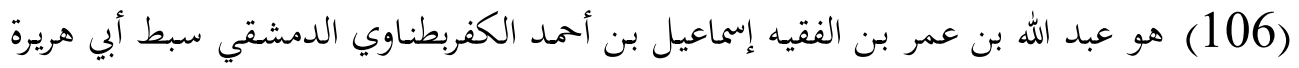

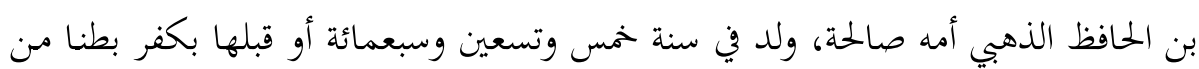

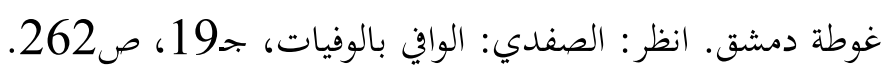

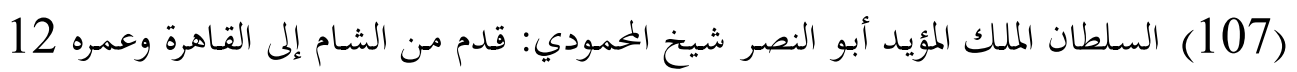

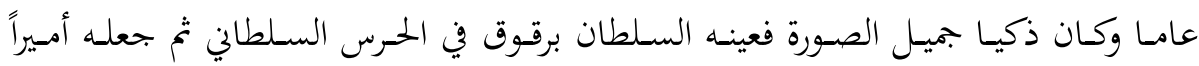

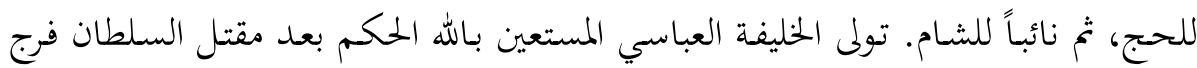

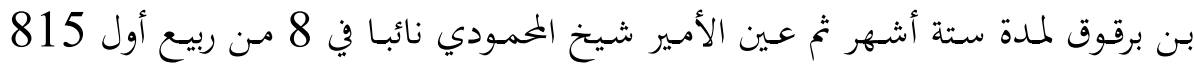

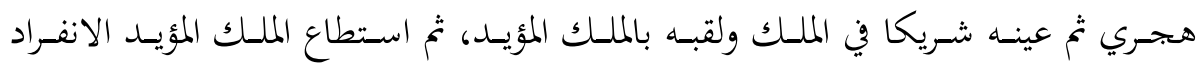
بالسلطنة في أوائل عام 815هـ/ 1412م، وأبعد الخليفة العباسي المستعين إلى الإسكندرية

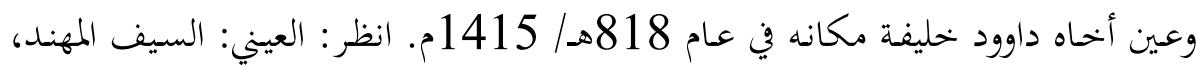

$$
\text { (108) العيني: السيف المهند، صحتقاب (أ - صن). }
$$

(109) Moufazzal Ibn Abil- Fazail, Histoire des Sultan Mamlouks, Tome III, pp. $532-533$. 